\title{
Understanding people's needs for a vivid public realm as a key towards enhancing modern neighbourhoods' liveability. Nasr City in Cairo as a case study
}

Merham M. Keleg, Marwa Abdellatif

Ain Shams University, Egypt

merhamkeleg@eng.asu.edu.eg I m.abdellatif@eng.asu.edu.eg

\begin{abstract}
Traditional cities emerged and grew according to the residents' needs; thus they were a reflection of the community's culture and traditions. But lately cities have witnessed numerous changes and challenges. Nasr City in Cairo was planned as a suburb in the late sixties to tackle the housing shortage in Cairo. Nasr city's master plan aimed at accommodating modern planning concepts where it featured an abundance of open public spaces when compared to other districts of Cairo. However, these spaces are empty of people most of the time, which detracts from the character and the experiential qualities of the area. This paper aims to explore the way in which the residents of Nasr city envision 'their' public spaces, comprehending the reasons why their usage of such spaces is currently hindered and discovering their recommendations for enhancing public spaces in their neighbourhoods in a way that would encourage them to visit them regularly. In addition, this paper assesses Nasr city's public spaces, in an attempt to bridge the gap between the offered built environment and people's needs. This assessment shall be achieved through the use of questionnaires, observations of people's reactions towards offered public spaces, urban surveys of the provided public spaces and interviews with officials. Based on these studies the paper proposes recommendations incorporating people's needs for a vivid public realm, in order to help planners and officials to understand the malfunctions inherent in modern city planning and management models that have hindered planned public spaces from conveying and fulfilling their role as centres of social interaction.
\end{abstract}

Keywords: local identity, vivid public realm, liveability, well designed public spaces, Nasr city, management model

To cite this article:

Keleg, M., Abdellatif, M. (2019). Understanding people's needs for a vivid public realm as a key towards enhancing modern neighbourhoods' liveability. Nasr City in Cairo as a case study. The Journal of Public Space, 4(I), 65-92, DOI 10.3289I/jps.v4il.53I

This article has been double blind peer reviewed and accepted for publication in The Journal of Public Space.

cc) (5) This work is licensed under a Creative Commons Attribution - Non Commercial 4.0 International License https://creativecommons.org/licenses/by-nc/4.0/ 


\section{General background}

Human settlement patterns have emerged as a result of specific needs expressed by various groups of people in that area; personal needs, climatic needs, cultural needs, economic activities, political or religious paradigms and so on. Old cities can be considered the storytellers of history as they convey many meanings and exude an ambiance that reflects the prevailing social, political, and cultural circumstances. People were the ones who shaped the places around them according to their individual and communal identities (Living Streets, 2012). Hence old cities had unique identities that are distinguishable throughout the world. However, modernism has introduced new lifestyles, altered social cultures and affected the business world. Modern cities have overlooked the human pace and public life in favour of facilitating automobile movement, accommodating the escalating urban population and the consequences of different economic paradigms. In an attempt to accommodate these changes, the 1933 Athens charter was proposed as one of numerous initiatives that aimed to ensure a healthy modern lifestyle whilst also accommodating modern challenges (automobiles, factories, population boom, rapid urbanization...etc.) (The Athens Charter, 1933). The main principles of the Athens charter called for a strict separation between land uses, high rise residential blocks and the facilitation of the movement of cars which has resulted in the latter being prioritised, overlooking the pedestrian pace (ibid). In addition to the prior challenges and changes in the physical environment that cities built in the modern era pose, economic liberalisation, social polarisation, and fragmentation that followed the modern era in the globalisation era have also helped turn public spaces into subjects of contestation (Oktay, 20I2). The effects of these challenges can be seen in the neglect, decline, privatisation, commercialisation and exclusive nature of public spaces (Oktay, 20I2); that in turn, have yielded a deteriorating and shrinking public realm that is losing its meaning in people's daily lives (ibid).

\section{A vivid public realm and cities' identities}

Identity of places is pillared by place attachment, spatial identity and the surrounding land uses (Dougherty, 2006). While Victoria argues that identity is mainly defined by the quality and diversity of the cultural activities and services in a place (Victoria, 2008). Hence it is people's reaction to the places they live in and the changes these places inspire in them that form the identity of a place (Dougherty, 2006). Meaningful social exchange builds a sense of belonging and community pride for residents (Choudhury, 2008). The social construct and interaction that take place in places are crucial for identifying a place's identity in people's lives. Place-identity is defined as 'the set of meanings associated with any particular cultural landscape which any particular person or group of people draws on in the construction of their own personal or social identities' (Watson \& Bentley, 2007, p. 6).

Public spaces are sometimes called the glue that binds cities together (Wellington City Coucil, 2008), which emphasises their importance in identifying cities identities, through people's perceptions and reactions to them. Namely, public spaces play a major role in urban structure by serving important urban functions as well as allowing for the interconnection and coherence between different spaces, contributing to urban cohesion and sustainability (úlia et al., 2010; Herzog, 2006), as well as defining public life in cities through strengthening the local spirit (UrbSpace, 2008). Public spaces contribute tremendously to social cohesion and local identity where they act as social 
catalysts; gathering residents together for various reasons and activities they take on symbolic meanings surrounding coexistence (Dougherty, 2006; Memluk, 20I3).

Precisely, the use of public space is crucial in defining its identity and by extension so is encouraging public space design that meets users' needs and faciliates diverse uses (Dougherty, 2006). In other words, people won't use the space unless they can identify with it and feel connected to it (Dougherty, 2006). Thus, many urban areas lack identity due to the diminished role of the provided public spaces which were planned or changed without concern for the environmental and social realities of the place (Dougherty, 2006; Georgopulos, 2005). Investment in the quality of the public realm which aims to foster cultural interactions can contribute to a revitalisation of deprived and abandoned urban spaces (Monroy, 2010). Hence urban spaces that reflect the residents of their cities act as the microcosms of the city that takes on its characteristics (Dougherty, 2006).

\section{Research problem}

Despite the great importance of public spaces to inhabitants, communities, and cities; not all public spaces are effective places. Dangerous roads, abandoned lots or poorly maintained properties and spaces are considered public spaces however they surely don't contribute to the well-being, coexistence, or cultural richness of cities and communities (PPS, 2015). On the contrary, poorly managed or inaccessible public spaces can act as barriers rather than collective spaces, where they become unsafe, exclusive, or threatening on different scales (PPS, 20I5). Hence creating public spaces for people requires more than simply providing the spaces (moveDC Vision, 20I4). Indeed, creating a collective space requires making attractive, functional, well maintained and safe places that attract people and offer them a comfortable environment adequate for spending time in (moveDC Vision, 20I4; PPS, 20I5). Moreover, designers should consider urban space as an aesthetic entity as well as a behavioural setting (Carmona et al., 2003). On the other hand, local community engagement is crucial in designing and shaping neighbourhoods and public spaces, as it offers a promising opportunity for creating socially, economically, and environmentally sustainable places (Living Streets, 20I2). In fact, this was the norm throughout the history, people have always been the shapers of the places around them which highlighted their individual and communal activity (Batty \& Longley, 1994; Living Streets, 2012). Hence a city's transformation should be an interplay between all forces; an exchange between elite groups of professionals and the people will be achieved by changing urban cultures and collective actions (Shaw \& Hudson, 2009). Designing for the needs of local residents reinforces the feeling of ownership of spaces (Deasy et.al., 1985), ensuring that neighbourhood spaces are successful and well used, which encourages residents to take the necessary actions to defend them (ibid). Thus, creating successful places depends on the skills of designers, the vision and the commitment of those who employ the designers (CABE, 2000), as well as the engagement and commitment of residents in order to create a place rather than a space (PPS, 2015). Community involvement is an essential element of good management (CABE, 2006). Moreover, an identifier of responsible management of spaces is where people and places are considered to be two sides of the same coin or synonyms (PPS, 20I4; RENEW, 2008). Herzele \& Wiedemann designate that a space has to be citizen-based as a guiding principle for public space provision in order that they subsequently reflect a people's point of view (Herzele \& Wiedemann, 2003). 
At this point, it is crucial to establish common ground by defining what is meant by the term public space for the purposes of this study. Broadly speaking, any place that promotes people's capacity to make acquaintances is considered a public space regardless of its size, shape, location, or ownership. However for the scope of this research, based on the globally agreed on definition of a public space as accessible for all, as well as the definition from the charter of public space: 'Public spaces are all places publicly owned or of public use, accessible and enjoyable by all for free and without a profit motive' (INU, 2013); the public spaces that will be studied are open, freely accessible outdoor spaces. Based on this definition, Nasr City, a modern suburb in Cairo has 43 public spaces distributed among the districts.

Despite the abundance of public spaces distributed in Nasr City, most of them are devoid of people most of the time. The issue of abandoned public spaces is clearly obvious where public spaces fail to convey their social and cultural function, jeopardising Nasr City's local identity.

\section{Case study: Nasr city background}

The first master plan for Cairo was issued in 1956 in order to guide and control development (UN, 1990). One of the main results of this master plan was the construction of a large town extension to establish Nasr City as a new government centre, (Abouelmagd, 20I I; UN, 1990). Nasr City was planned on vacant desert land on an area spanning $250 \mathrm{~km}^{2}$, and its construction began in 1965 (Abouelmagd, 20 I I), lead by Madinet Nasr a housing and development company which was founded in 1959 (Madinet Nasr for Housing Development, 20I2).

Nasr city was designed at a time when modern architects had the opportunity to innovate and implement their ideas around the world. Architects who were active in this period got rid of traditional planning ideologies and designed new cities and urban spaces according to the new lifestyles that prevailed during this period (Frochaux \& Martin, 2010). Nasr City was built according to the 1933 Athens charter guidelines, where the southern part of Nasr City was planned as the residential area of this extension (Frochaux \& Martin, 2010). The residential area was planned in a grid pattern by Dr. Sayed Koriem and was divided into I0 districts (Eid, et al., 20I0; Frochaux \& Martin, 2010). This characteristic plan of Nasr City featured straight routes serving equally shaped geometrical land plots (Eid, et al., 2010; Frochaux \& Martin, 2010), and each zone was planned around a centre for high level services which would serve the neighbourhoods collectively (Eid, et al., 2010). In turn, each neighbourhood contained its own smaller service centre situated at its heart, where both goods necessary for everyday life and a place where neighbours could meet were provided (Frochaux \& Martin, 2010). Relative to other parts of Cairo, this Nasr City plan boasted an abundance of green open spaces (ibid). However, the orthogonal system has failed to produce any hierarchisation of spaces, as there is no focus on converging axes that makes emphasising a building or a space possible? (ibid).

\section{Methodology}

In order to understand the dilemma of the abandoned public spaces of Nasr City as a step towards enhancing its identity, it is important to understand the reasons for the gap between people's needs and the built environment. This shall be achieved through a 
field observation of the provided public spaces in order to assess the qualities of the provided built environment; in addition to holding a questionnaire among Nasr City residents with the aim of comprehending their recommendations for better public spaces, understanding what changes would need to be adopted in order to encourage them and increase their willingness to use these public spaces. Furthermore, interviews with officials were undertaken to discover and understand the management model and legislations of public spaces in Nasr City.

The field observations were documented and assessed according to a checklist of physical aspects that were concluded from the literature. While the questionnaire was divided into two parts; the first part is dedicated to the participants' evaluation of the current status of the space, including their perception of the provided spaces, in terms of the function of these spaces in their point of view and their recommendations for enhancing their experience there and encouraging more visits and usage; whereas, the second part is dedicated to the participant's personal data. The questionnaire was done on site mostly during field observations, whether passers-by or active users of the spaces, all of the respondents were local residents. The interviews were conducted later on in the assesment process, after the field observations and the questionnaire results analysis, so that the authors would have the benefit of a holistic understanding of and a better grip on the current situation, its problems and its potentials. The interviews were held with the officials of the executive bodies responsible for managing these spaces, who were mainly asked about: the body's vision towards these spaces and their usability; the management models of the spaces; variances in the quality of maintenance between the spaces as explored during the field observations; the different levels of accessibility; and the reasons behind the different design models between the spaces.

\section{Qualities of well-designed public spaces}

A vivid public realm can be achieved through the provision of a comfortable and welcoming environment that is suitable for all age groups, vibrant with people enjoying themselves in the company of others and where safety and security are assured, even at night (An Urban Design Protocol For Australian Cities, 20l I). Thus, it is essential to concentrate on creating attractive, intricate places that relate to the scale of walking people not to the scale of moving cars (Tibbalds, 2004). Moreover, individuality, distinctiveness, and differences between places should be celebrated in order to create an attractive public realm that promotes a feeling of well-being and comfort (ibid). For instance, places that stimulate a feeling of physical and psychological well-being are spaces that are thoroughly pleasant places to be in, spaces that create an unforgettable total impression (Ewing et al., 20I3). This can be accomplished when all factors manage to work together in order to achieve pleasing ends (ibid). There is no magical formula for creating successful public spaces but as the literature suggests there are crucial preliminary qualities that help ensure the liveability of public spaces. These qualities have been defined and argued by numerous authors and initiatives throughout the last few decades. Through an extensive literature review of the main theories and practices that discuss the qualities of successful and liveable public spaces, the common and main qualities were classified, categorised and analysed to form the main checklist for assessment in this research, as illustrated in Table I. The literature review included theories developed by urban design pioneers, scholars' journal articles, online sources 
and in addition, organisations' and public realm manuals'. The checklist includes qualities that range from the macro-scale to the micro-scale, from purely tangible physical factors to intangible social factors as illustrated in Table I. Thereafter, the aspects of each quality are used as a basis for the checklist for assessing the public spaces in Nasr City.

Table I. Main qualities of well-designed public spaces. Source: the Authors compiled from different references.

\begin{tabular}{|c|c|c|c|c|}
\hline & Quality & Definition & Aspects & Checklist Threshold \\
\hline \multirow{4}{*}{ 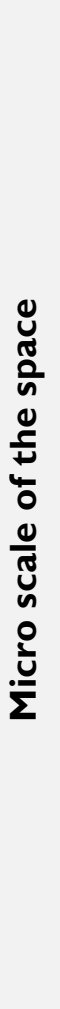 } & \multirow{2}{*}{ 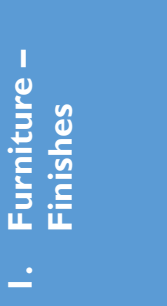 } & \multirow{2}{*}{$\begin{array}{l}\text { The furniture in the public space } \\
\text { and the way it is arranged is the } \\
\text { welcoming gesture these spaces } \\
\text { offer to the users. }\end{array}$} & $\begin{array}{l}\text { Primary seats as well as } \\
\text { secondary sitting } \\
\text { opportunities. }\end{array}$ & $\begin{array}{l}\text { Presence of seats in the } \\
\text { space }\end{array}$ \\
\hline & & & $\begin{array}{l}\text { Encourage diversity of users } \\
\text { through different sitting } \\
\text { settings and materials }\end{array}$ & $\begin{array}{l}\text { At least } 2 \text { settings in the } \\
\text { space (couples and group } \\
\text { settings) }\end{array}$ \\
\hline & 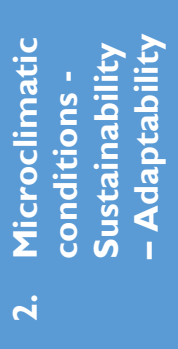 & $\begin{array}{l}\text { Enhancing the microclimatic } \\
\text { conditions of the spaces implies } \\
\text { protection from adverse climatic } \\
\text { changes as well as protection } \\
\text { from any threatening noise }\end{array}$ & $\begin{array}{l}\text { Incorporation of natural } \\
\text { elements like plants, trees, and } \\
\text { water is encouraged in public } \\
\text { spaces for numerous reasons. }\end{array}$ & $\begin{array}{l}\text { Any act of sustainability } \\
\text { and/or climate adaptation } \\
\text { feature }\end{array}$ \\
\hline & 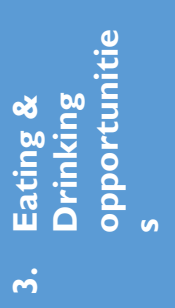 & $\begin{array}{l}\text { Different amenities offer people } \\
\text { different opportunities for their } \\
\text { engagement in the public life. }\end{array}$ & $\begin{array}{l}\text { Cafes and food van provisions } \\
\text { in public spaces or at the } \\
\text { edges. }\end{array}$ & $\begin{array}{l}\text { Presence of at least I } \\
\text { opportunity }\end{array}$ \\
\hline
\end{tabular}

\footnotetext{
' The literature review included the theories of urban design pioneers (Alexander, et al., 1977; Carmona, et al., 2003; Deasy, et al., 1985; Efroymson, et al., 2009; Gehl, 2001; Jacobs, I96I; Krier, 1979;

Madanipour, 2003; Shaftoe, 2008; Stevens, 2007; Tibbalds, 2004; WALLJASPER, 2007; Whyte, 1980; Whyte, 2009), scholars' journal articles (Ben-Joseph, 1997 ; Goheen, 1998; Herzele \& Wiedemann, 2003; Júlia, et al., 2010; Moore \& Cosco, 2007; Samadi \& Hasbullah, 2008; Serdoura \& Ribeiro, 2006), online sources (Gomes, 2012; Lennard, 2004) in addition to organizations \& public realm manuals (CABE, 2000; CABE, 2006; CABE \& DETR, 200I; Gehl Architects, 2007-2009; Living Streets, 20I2; Municipal Spatial Planning Support Programme.(MuSPP), 2012; North West Regional Development Agency, 2008; PPS, 2014; RATIO Architects, 2003; RENEW, 2008; Worpole \& Knox, 2007).
} 


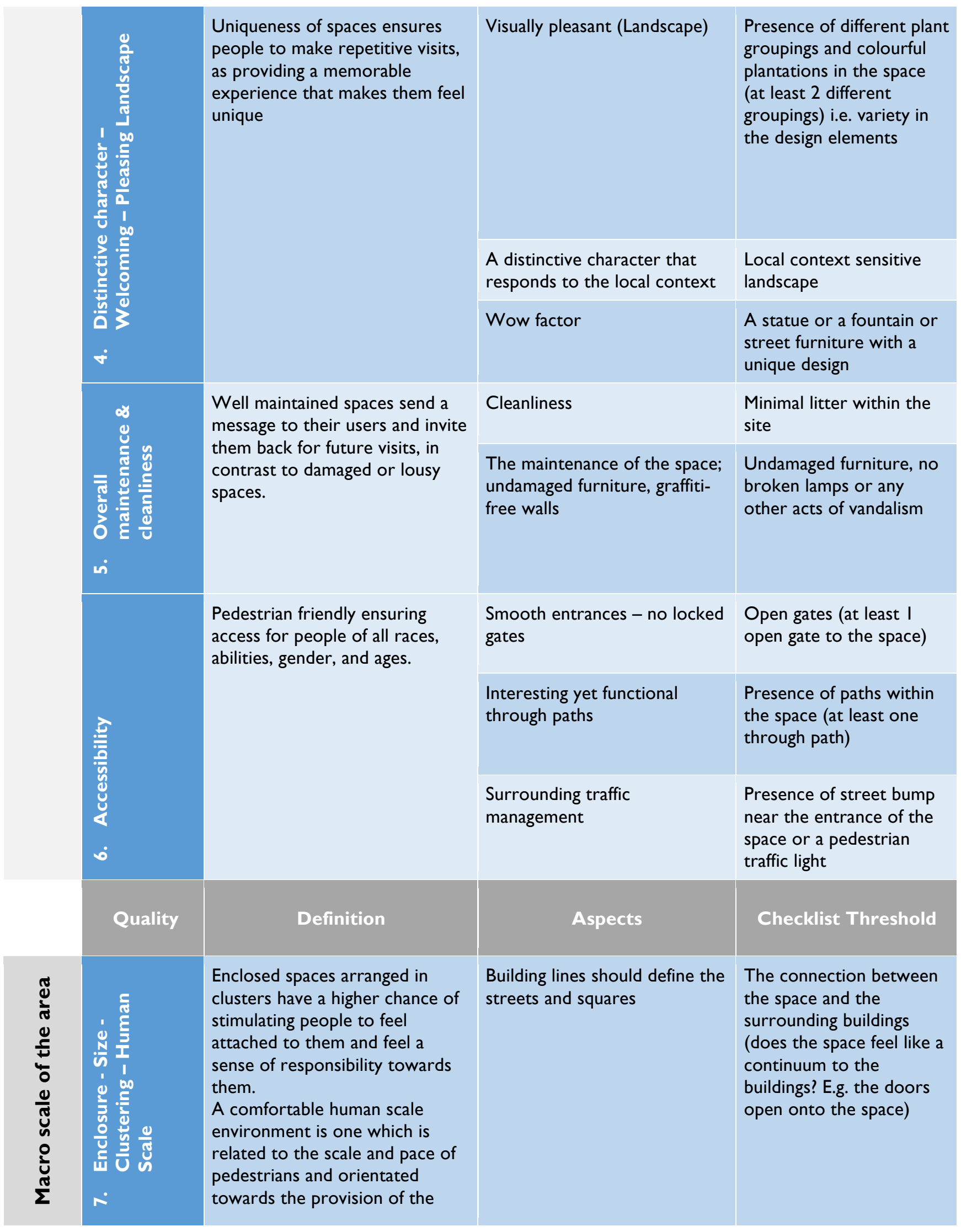




\begin{tabular}{|c|c|c|c|}
\hline & $\begin{array}{l}\text { feeling of comfort and by } \\
\text { extension, pleasure. }\end{array}$ & Smaller clearly defined spaces & $\begin{array}{l}\text { Small public space shall } \\
\text { have a radius that ranges } \\
\text { between } 12 \mathrm{~m} \text { to } 24 \mathrm{~m} \text { as a } \\
\text { maximum distance. This } \\
\text { distance is purely deduced } \\
\text { from human needs and } \\
\text { dimensions. }\end{array}$ \\
\hline 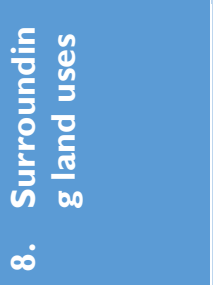 & $\begin{array}{l}\text { The relationship between the } \\
\text { street and the public space } \\
\text { should be continual. }\end{array}$ & $\begin{array}{l}\text { Mixed and vivid land uses } \\
\text { should always be situated } \\
\text { around public spaces, } \\
\text { especially at the ground floor } \\
\text { level }\end{array}$ & $\begin{array}{l}\text { Presence of active land } \\
\text { uses at least by the } \\
\text { entrance of the space if } \\
\text { fenced }\end{array}$ \\
\hline 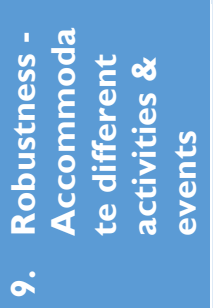 & $\begin{array}{l}\text { Meet the needs of diverse users } \\
\text { belonging to different age } \\
\text { groups, classes and so on. }\end{array}$ & $\begin{array}{l}\text { Responsive public space design } \\
\text { that provides a range of } \\
\text { choices with features that } \\
\text { define the space rather than } \\
\text { dominate it }\end{array}$ & $\begin{array}{l}\text { The presence of at least a } \\
\text { flat open space within the } \\
\text { space that could } \\
\text { encourage different } \\
\text { activities (playing football, } \\
\text { cycling, group games) }\end{array}$ \\
\hline \multirow{3}{*}{ 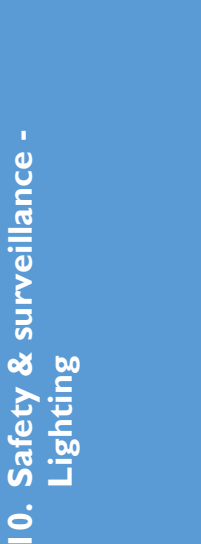 } & \multirow{3}{*}{$\begin{array}{l}\text { Pedestrians of all ages and } \\
\text { abilities feel unthreatened and } \\
\text { safe around the clock, especially } \\
\text { at night, low crime statistics } \\
\text { within the space, and free of any } \\
\text { anti-social behaviour }\end{array}$} & Space is overlooked & $\begin{array}{l}\text { Security personnel or } \\
\text { gardeners in the space }\end{array}$ \\
\hline & & $\begin{array}{l}\text { Ensuring good visibility of the } \\
\text { space }\end{array}$ & $\begin{array}{l}\text { Opportunities for passive } \\
\text { surveillance ( able to see } \\
\text { through the space from } \\
\text { the street) }\end{array}$ \\
\hline & & Adequate lighting & $\begin{array}{l}\text { Light posts along the } \\
\text { paths within the spaces } \\
\text { and along the periphery }\end{array}$ \\
\hline 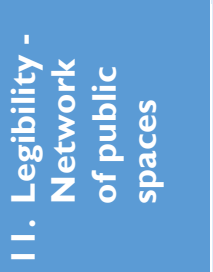 & $\begin{array}{l}\text { Planning city spaces to act as a } \\
\text { series of linked sequences of } \\
\text { nodes in terms of pedestrian } \\
\text { movement }\end{array}$ & & $\begin{array}{l}\text { Connecting pedestrian } \\
\text { paths between the spaces }\end{array}$ \\
\hline
\end{tabular}




\begin{tabular}{|c|c|c|c|c|}
\hline & Quality & Definition & Aspects & $\begin{array}{l}\text { Checklist } \\
\text { Threshold }\end{array}$ \\
\hline \multirow[b]{2}{*}{ 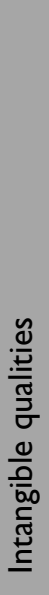 } & 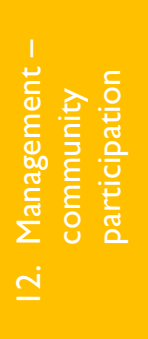 & $\begin{array}{l}\text { A sense of inclusion is directly } \\
\text { related to and reinforced by } \\
\text { empowerment and civic } \\
\text { engagement. An identifier of } \\
\text { responsible management of spaces } \\
\text { is where people and places are } \\
\text { considered to be two sides of the } \\
\text { same coin or synonyms. }\end{array}$ & & $\begin{array}{l}\text { Presence of a } \\
\text { community board or } \\
\text { a community } \\
\text { member within the } \\
\text { management board } \\
\text { of the space. }\end{array}$ \\
\hline & 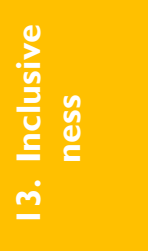 & $\begin{array}{l}\text { Inclusive public space is welcoming } \\
\text { to all where everyone feels } \\
\text { welcome by working effectively for } \\
\text { all in the community, including the } \\
\text { disabled, elderly people, teens, and } \\
\text { children. }\end{array}$ & $\begin{array}{l}\text { Generating social dynamics } \\
\text { through complementary public } \\
\text { spaces and available activities is } \\
\text { a crucial element of urban } \\
\text { cohesion }\end{array}$ & $\begin{array}{l}\text { Different age groups } \\
\text { and genders using } \\
\text { the space (at least } \\
\text { both genders and } 2 \\
\text { age groups) }\end{array}$ \\
\hline
\end{tabular}

Table 2. Sample of the checklist assessment for public spaces used in Nasr City. Source: The Authors.

\section{Results}

\section{I Field Observations Results}

The 43 public spaces in Nasr City were assessed by the authors according to the checklist, each aspect was verified for its presence or lack of presence, then a point assigned for each existing aspect. However, the intangible qualities (management and inclusiveness) were verified through observations and interviews with officials in order that they be clearly analysed and understood.

\section{I.I Tangible factors analysis}

A sample of the assessment checklist is illustrated in Table 2, where this public space was selected as an example of the prevailing current status of Nasr City's public spaces (spaces whose results range from I to 4 points, which constitutes 34 spaces out of the 43 public spaces in Nasr city). Then the space is further documented in pictures as shown in Table 3. Most of the 34 spaces share similarities with the features and characteristics outlined in this example.

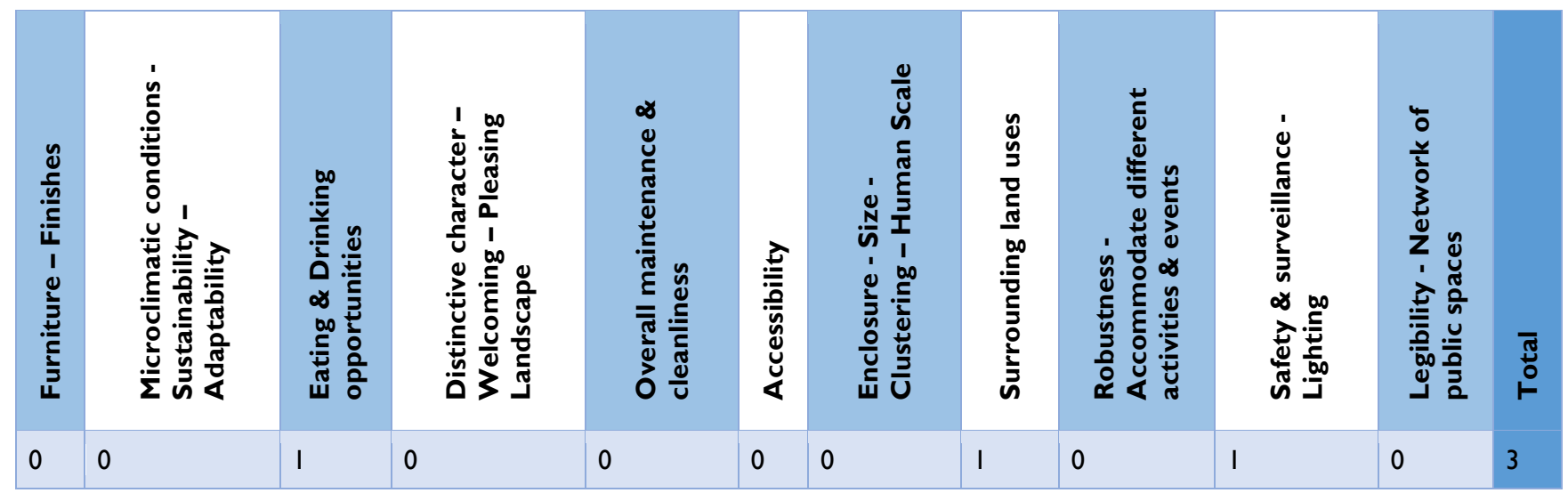

Table 3. Current status of the selected public space in pictures, sorted according to the pre-defined qualities used in the assessment checklist. Source: The Authors. 


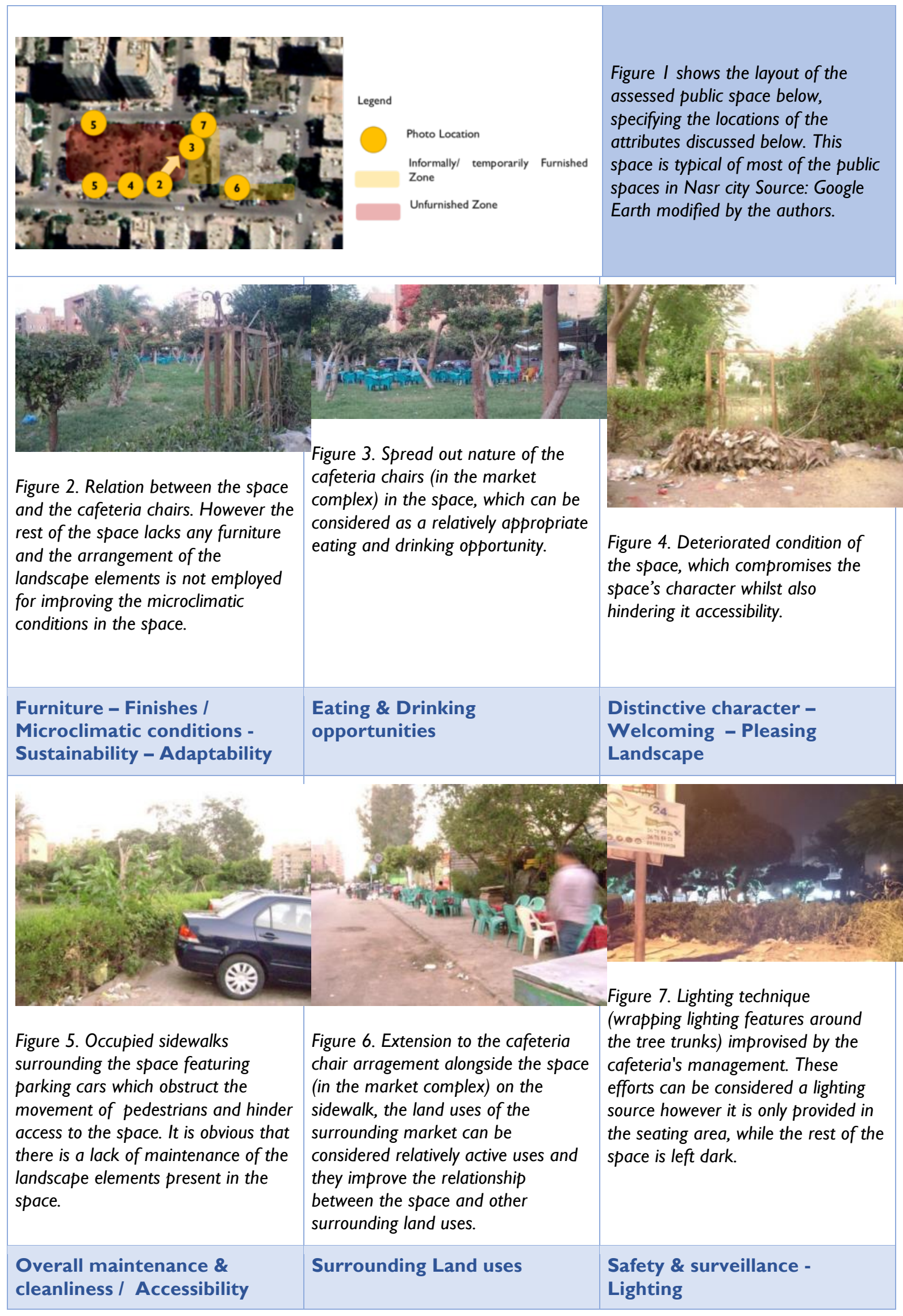

74 | The Journal of Public Space, 4(I), 2019| ISSN 2206-9658

City Space Architecture / UN-Habitat 
Similarly, the points assigned to other public spaces are summarised and then represented on a city map as shown in Figure 8. From the map it is obvious that most public spaces in Nasr City lack most of the qualities that should be provided in order to encourage people to use them. This justifies the current situation where people are not attracted to use these public spaces due to their unpleasantness, the result of which is that they end up being abandoned, which in most cases also renders them unsafe. It can be concluded that Nasr City faces an overwhelming, neighborhoods-wide public space malfunction.

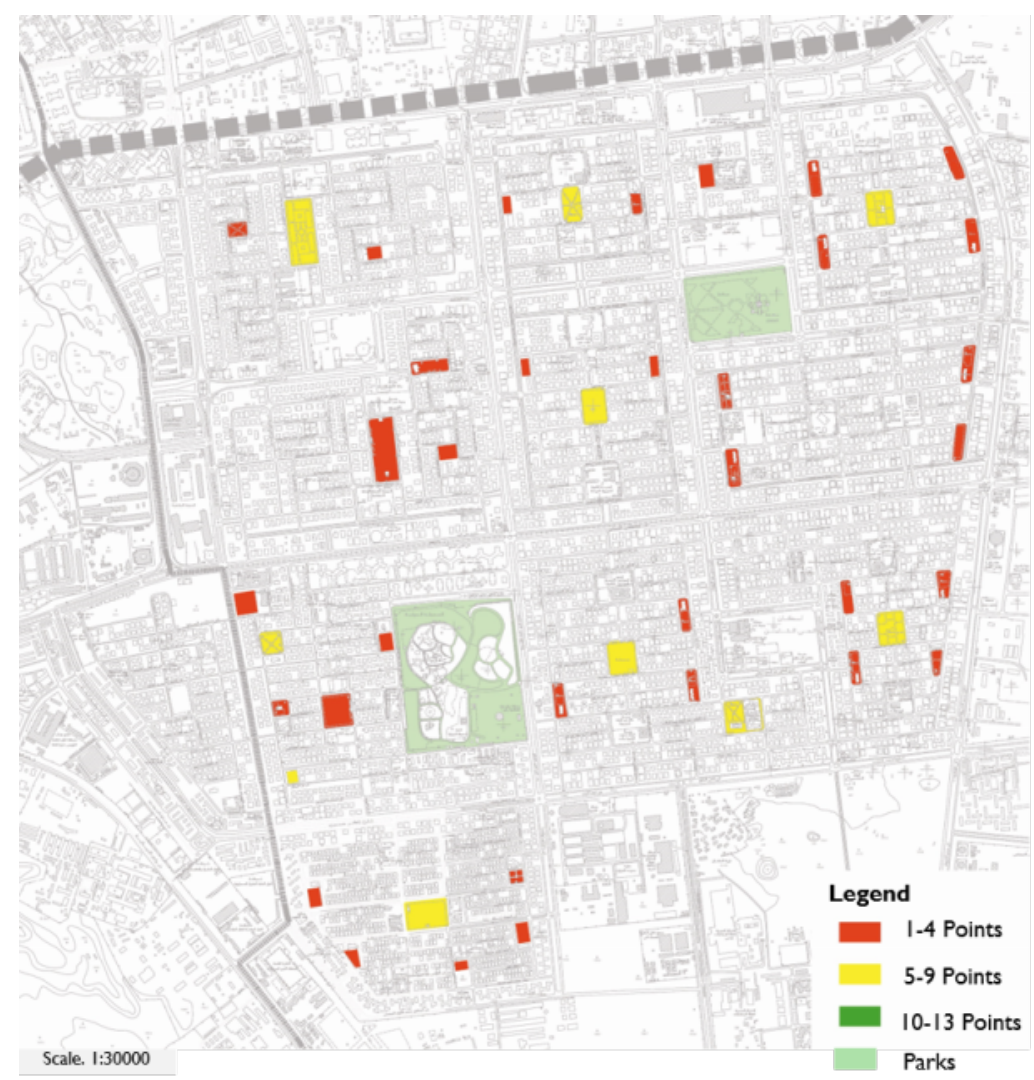

Figure 8. Points that were given to each public space in Nasr city according to the checklist. Source: The Authors

On the other hand, a cross sectional analysis of Nasr City's public spaces was used afterwards in order to explore the holistic situation of Nasr City's public spaces and to highlight the main assets and malfunctions that are common for most of the public spaces as shown in Figure 9.

It is obvious that most of them have eating and drinking opportunities however this number may be a bit misleading as these opportunities are related to the markets or kiosks that are found beside most of the public spaces. It was observed that they don't attract diverse sectors of the residents due to their being in bad condition and their problematic lack of seating. The presence of eating and drinking opportunities should be accompanied by seats in order to encourage users to grab the food and enjoy it in the open air; this is not the case for Nasr City's public spaces. In some cases, the nearby cafes within the markets use the premises of the nearby public spaces to extend their 
seating area. However, this is illegal according to Egyptian law and is considered an encroachment on public entities (Interview with CCBA official, 2017).

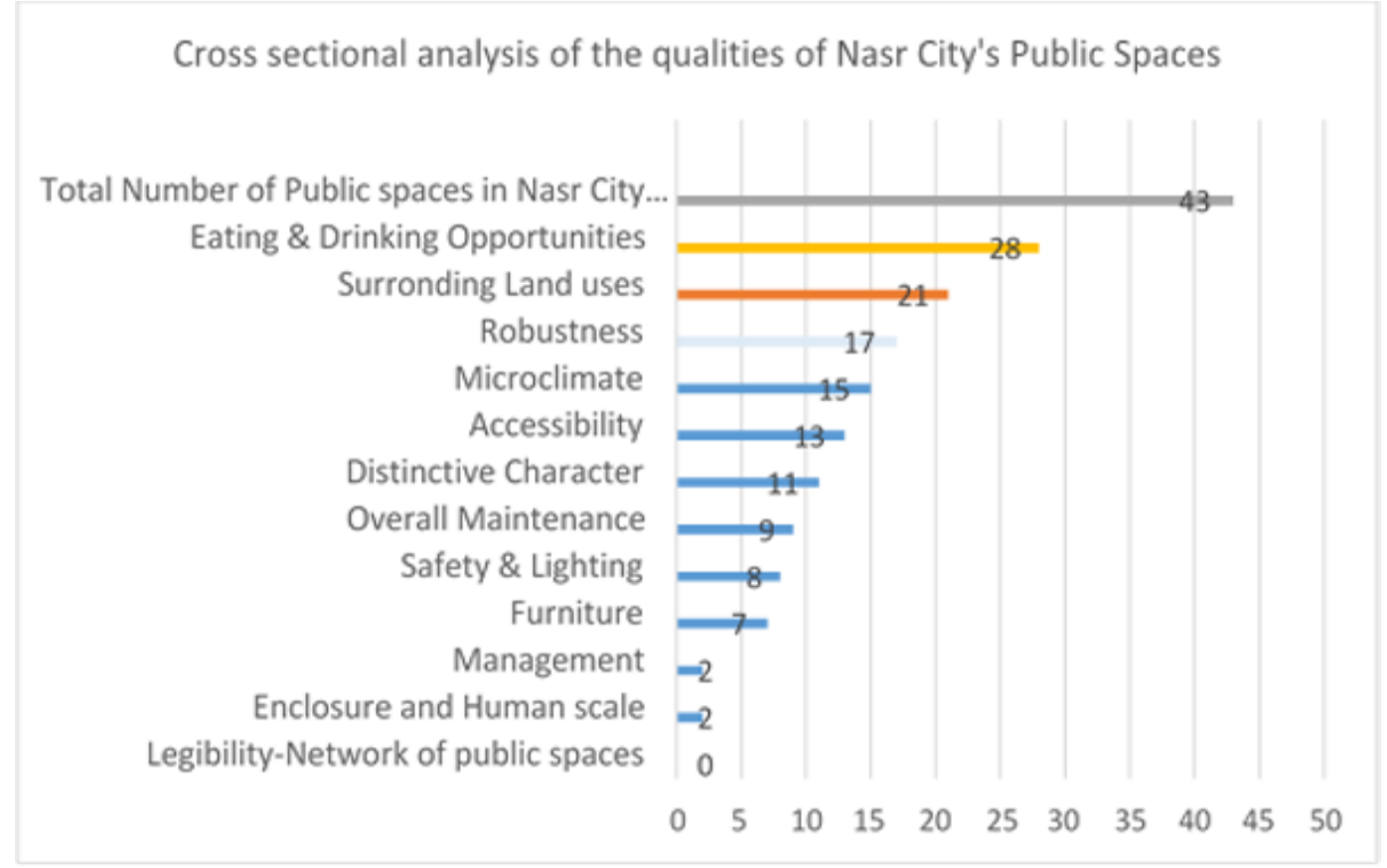

Figure 9. Results of the cross-sectional analysis of the design qualities of Nasr City's public spaces according to the checklist. Source: The Authors

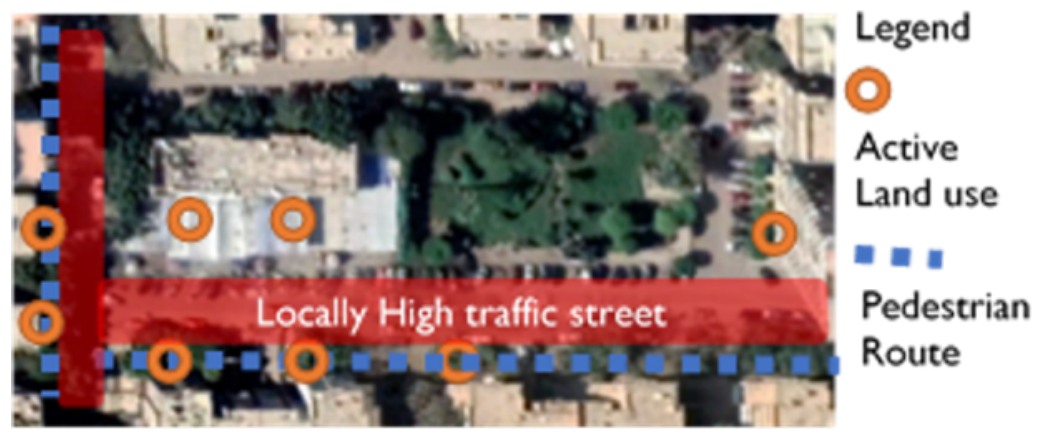

Figure 10. Relationship between the spaces and the surrounding land uses and pedestrian routes. Source: Google Earth modified by the Authors.

According to the checklist, active land use along the periphery can be considered to add value to the space where it attracts residents to use the spaces, this was also verified to be true through observation.

The second feature that was observed intensively pertained to the vivid surrounding land uses observed at the ground floor level in Nasr City, which for the most part has been transformed into shops and cafes rather than purely residential units. This quality might offer passive surveillance of passers-by, shop merchants and around the clock activities in these public spaces, but the separation of public spaces and surrounding land uses by streets has degraded this effect, where public spaces are disconnected from pedestrian routes, as illustrated in Figure 10. 
All the public spaces scored low for enclosure and legibility, which is the result of top down planning where the human scale is more often overlooked. Clearly, human scale, pedestrian pace and human senses weren't taken into consideration in the process of producing the master plan for Nasr City.

\section{I.2 Intangible factors analysis}

In addition to the checklist used for assessing the tangible factors, the intangible factors were assessed through observations and interviews with officials in order to better understand the situation.

\section{I.2.I Management - community participation}

In order to assess the empowerment levels of Nasr City residents in the management of their public spaces, it is essential to understand the management model of public spaces adopted by the authorities. The management and maintenance of public spaces in Nasr City is assigned to the Cairo Cleaning \& Beautification Agency (CCBA) which is an agency responsible for the design, maintenance and management of the green areas in Cairo, along with other missions (Cairo Cleaning \& Beautification Agency, 2016). However, the ownership status of these spaces is assigned to the Cairo Governorate and the municipalities (Interview with CCBA official, 20I7). The mission of the CCBA, and its administration and organisational models, is mainly concerned with the physical aspects of the spaces and the agency's main task, related to the scope of the research, is the greening of spaces and landscape maintenance which is managed according to a restricted, low budget assigned to them by the governorate (Cairo Cleaning \& Beautification Agency, 2016). Thus, the CCBA deals with these spaces as green areas with no reference to their being public spaces, and so the social aspect is more often than not entirely overlooked. In fact, the social aspect is not mentioned as one of the mandates of the agency, rendering it a "no man's job" within the Egyptian organisational setting.

The CCBA has a central managerial model, in which the central unit designs, funds, and manages all the logistical and financial issues related to green areas in Cairo; it has executive local units located in different districts that are mandated with the implementation of the plans and the guidelines of the central unit (Interview with CCBA official, 2017).

This organisational setting deprives the spaces of unique and innovative local designs that would add to the character of the different neighbourhoods. This state of affairs does not allow for the participation of the communities in design because the local units are not mandated with any design tasks and so lack technical expertise; community engagement is not an easy task within this setting and is clearly not on the horizon from the point of view of the organisation. As engagement and empowerment usually take place at the local level, where a platform that gathers the community of each neighbourhood easily is required. In this sense, Christopher Alexander argues that a relationship and so a prominent effect between the local government and the community shall be attained only if there is an immediate link between the people and the officials (Alexander et al, 1977). Thus, he is advocating for decentralising the governments in a way that assigns them to control a community ranging from 5,000 to 10,000 persons. In this way the distance between the people and the centres of power is diminished, and at the same time communities shall be able to organise themselves as a corporation to maintain and discuss the common land they share. (ibid). This is 
obviously not the case in Nasr City, as aforementioned the centralisation of the CCBA hinders ease of communication between the people and the organisation, and so makes it harder for empowerment and participation to be attained.

On the other hand, the CCBA has a department assigned to self-efforts funding, which is mandated with managing the funds raised by residents while providing technical assistance and man-power to renovate nearby public spaces and green areas (Interview with CCBA Projects Manager, 20I7). In Nasr City, there is a public space that was reclaimed through this department, where the local residents gathered the essential funds and provided the required materials for the reclamation of the space. This space is uniquely different from the other spaces in the city, which adds to the character of the neighbourhood; the paving materials used are unique to those used in any other space, the design is also subtly different. In general, the CCBA has nurseries and stock materials that are almost always utilised in their projects, this practice and paradigm detracts spaces from the unique local character of each neighbourhood which surely affects the identity of the city as a whole, as illustrated in Figure II, Figure 12, Figure I3 and Figure 14.
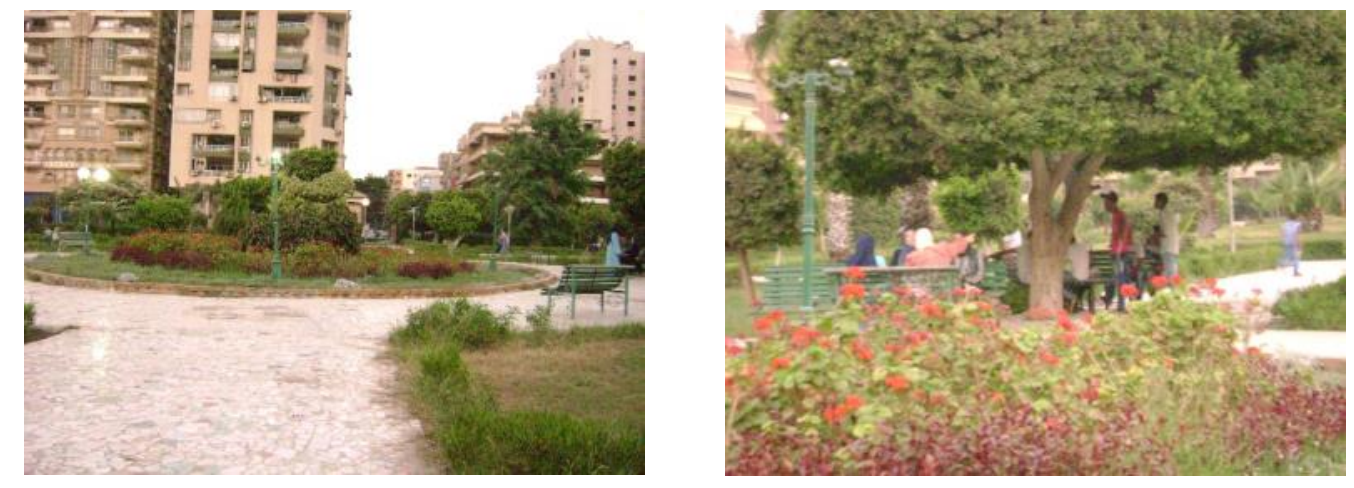

Figure II and Figure I2. Paving material and design of the public spaces renovated with self-funding by residents. Source: The Authors
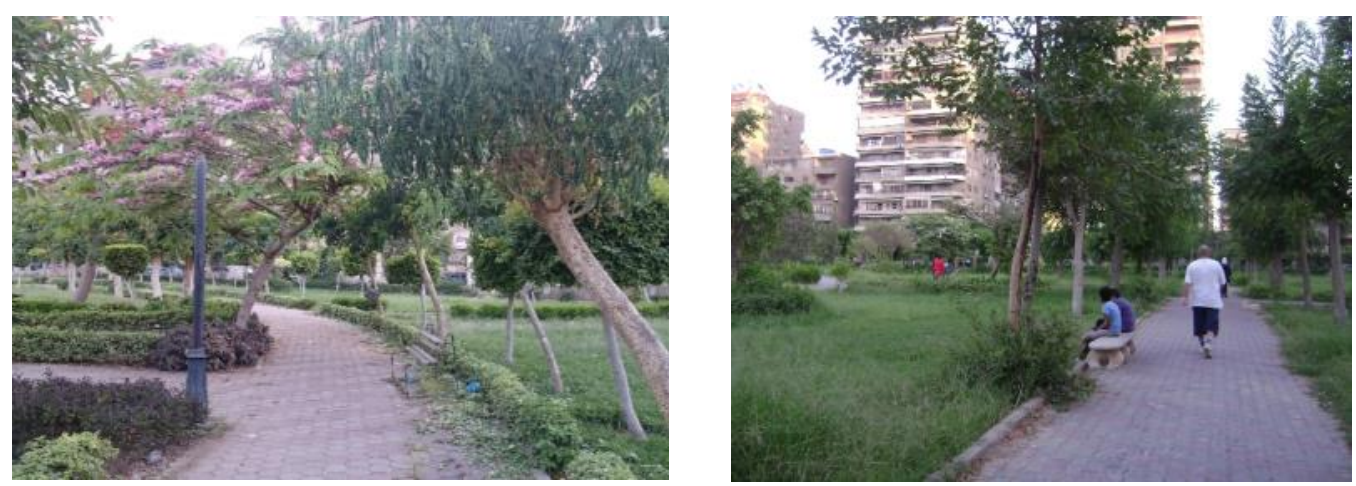

Figure 13 and Figure 14. Mainstream paving material used by the CCBA in almost all of Cairo's open spaces which detracts from the local character of each of the different zones. Source: The Authors. 


\section{I.2.2 Inclusiveness}

During the field observations, it came to light that there are two design models for public spaces in Nasr City that attract people differently. The first model is realated to central spaces in neighbourhoods that span relatively larger areas, as shown in Figure 15. These spaces are relatively better maintained by the CCBA, have defined and paved paths, seats and some of them even have coffee shops and playgrounds within their boundaries, as illustrated in Figures 17 and 19. There is also a significant presence of security officers and lighting poles distributed around the space. These spaces are used by almost the whole of the surrounding community including different age groups and vulnerable community groups, as illustrated in Figure 16; it is clear that these spaces constitute a significantly low percentage of the provided spaces in Nasr City (only 6 spaces out of 43 public spaces). While on the other hand, it was observed that the spaces nearby the markets (peripheral public spaces, illustrated in Figures 18 and 20) are sometimes used by the cafes located in the market complex as extension areas for their seating arrangements, as aforementioned. However, in most cases these spaces are not attractive or inclusive for the whole community. This model is mainly used by youths and males, with few exceptions.

Thus public spaces in Nasr City are far from being all-inclusive by any means, some of them invite and attract all the segments of the community, but most of the spaces are not used by all segments equally, which requires further analysis as to in what ways the needs/expectations of the different segments are in conflict with the commodities that these two models of spaces provide.

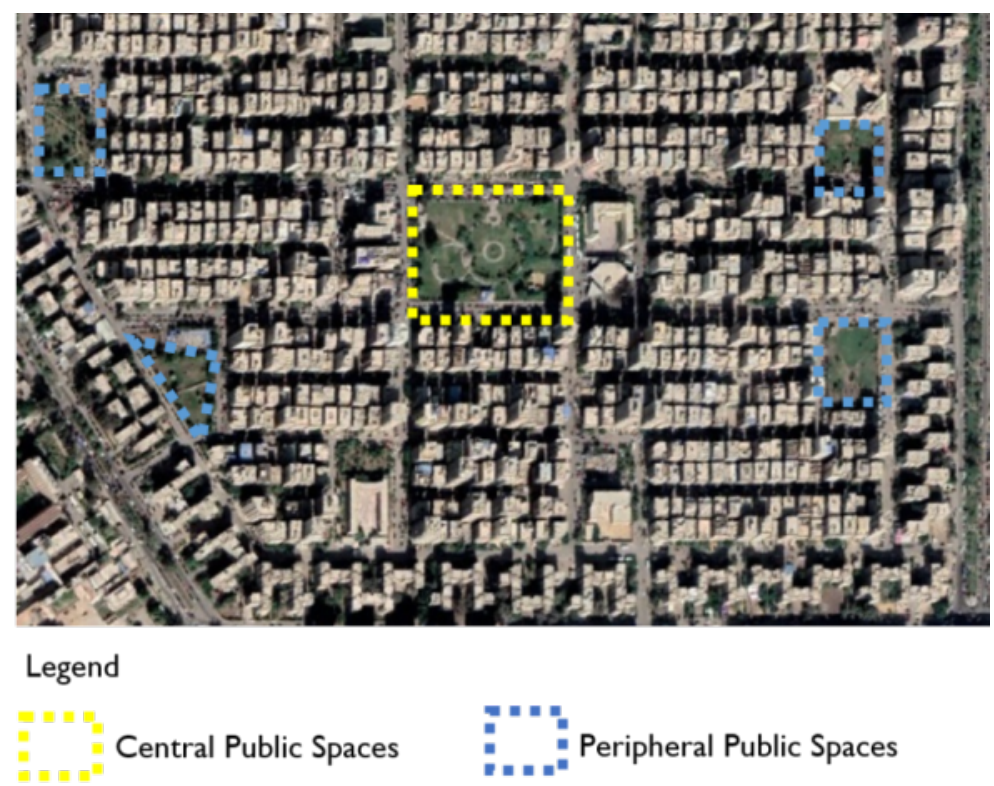

Figure 15. Liveable spaces that engage almost the whole community (central public spaces within the different zones of the neighborhoods). Source: The Authors. 


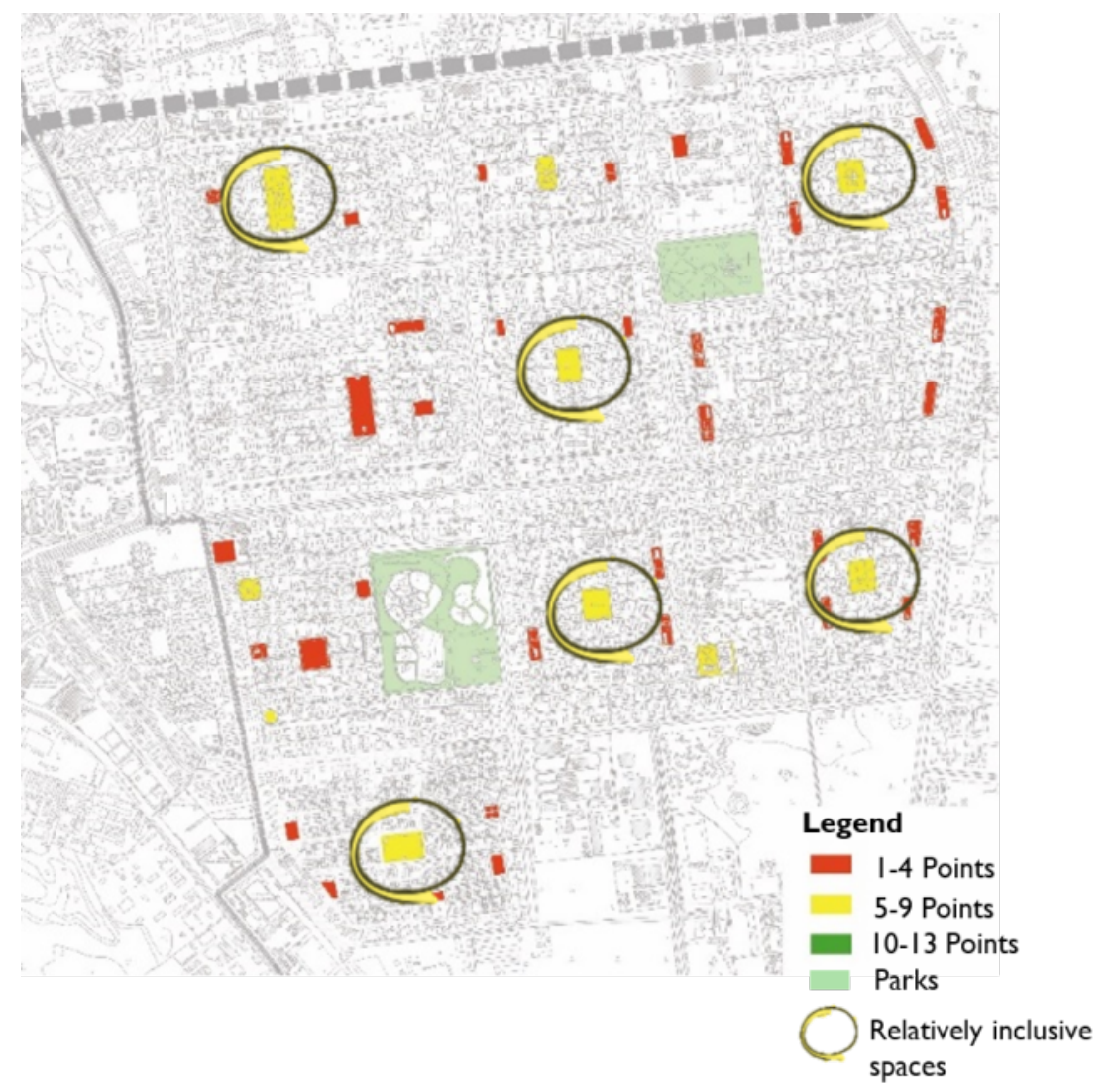

Figure 16. Spaces that were livable with almost all of community sectors (central public spaces within the different zones of the neighborhoods). Source: The Authors

\subsection{Questionnaire results}

The questionnaire was distributed among Nasr City residents. The sample consisted of 46 respondents, $43 \%$ of which were male and $57 \%$ female. The respondents' ages ranged from 12 to $60+$, however the largest segment represented was made of up individuals ranging from 18 to 34 years of age. They were asked about their recommendations for improving public spaces in ways that would encourage residents to increase their use of these spaces as shown in Figure 21. There is a consensus that the main needs for improving the public spaces are; regular maintenance, providing seating opportunities and amenities (furniture), and assuring personal safety. These three qualities stood out as being highly significant among other more general suggested requirements, which highlights their importance as essential factors for encouraging people to use public spaces. Further required needs were later agreed on relating to the provision of attractive landscapes and the facilitation and accommodation of various activities. Thereupon the residents were asked if they would use these spaces if their mentioned recommendations were accommodated. The result of this questioning was that $63 \%$ said that they would probably use them while $34 \%$ said that they were not sure, and only $3 \%$ said that they still wouldn't use public spaces, which indicates a prominent willingness to use the spaces if the outlined needs were provided for. 
Table 4. Differences in levels of maintenance and attractiveness between the two public spaces models in Nasr city.

\section{Example of Central Public Spaces}

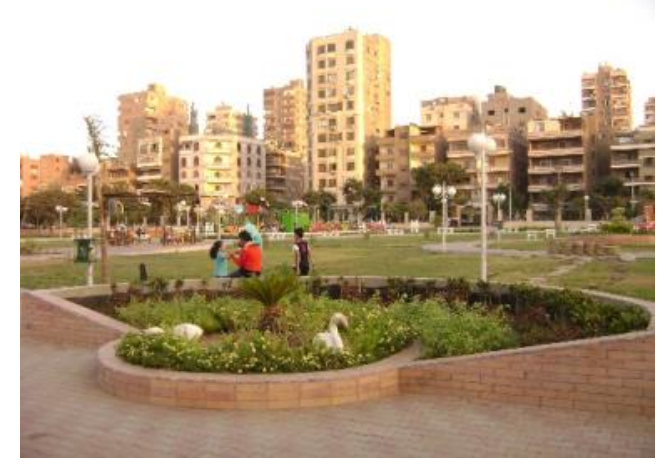

Figure 17 illustrates a level of maintenance that is considered to be relatively good in central public spaces. Source: The Authors

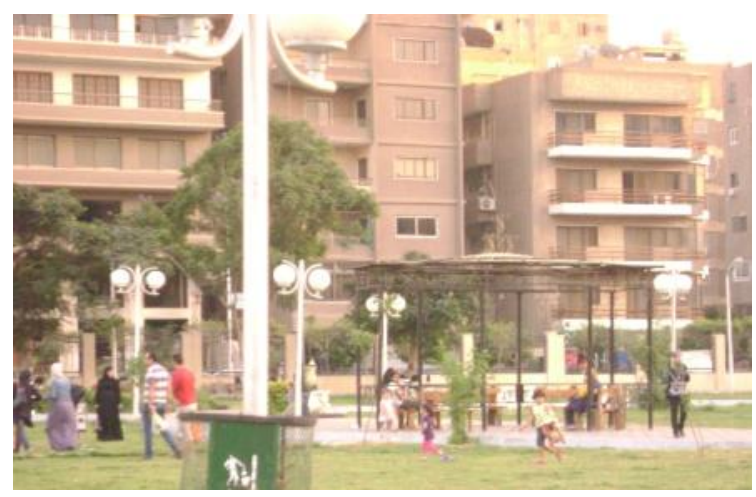

Figure 19 illustrates the attractiveness of the spaces and their being used by different segments of the community, including different age groups. Source: The Authors.

\section{Example of Peripheral Public spaces}

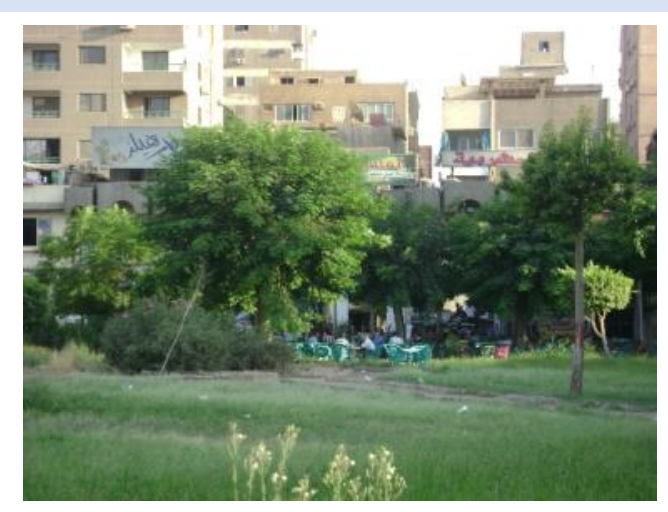

Figure 18 illustrates the level deterioration in maintenance in peripheral public spaces, some of which have markets and cafes on their peripheries as in this example. Source: The Authors.

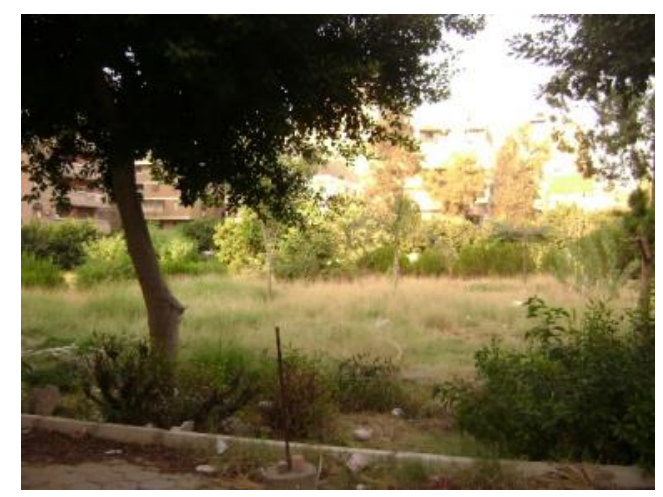

Figure 20 illustrates the prevailing status of abandonment. Source: The Authors.

\subsection{Analysing the needs of the different community segments}

Through a deeper analysis of the current situation in public spaces in Nasr City, the residents' recommendations shall be analysed and discussed in relation to the gender and the age range of the respondents in order to get to a holistic understanding of the collective needs, such that the level of inclusiveness attained by the different models of public spaces can be further understood.

\subsubsection{According to gender}

Despite some similarities, it is obvious from the graph in Figure 22 that males prioritise seating areas, security and good management, as well as better landscaping and better lighting when it comes to their using public spaces. While females mainly prioritise regular maintenance, the provision of amenities, as well as better lighting. 
Understanding people's needs for a vivid public realm

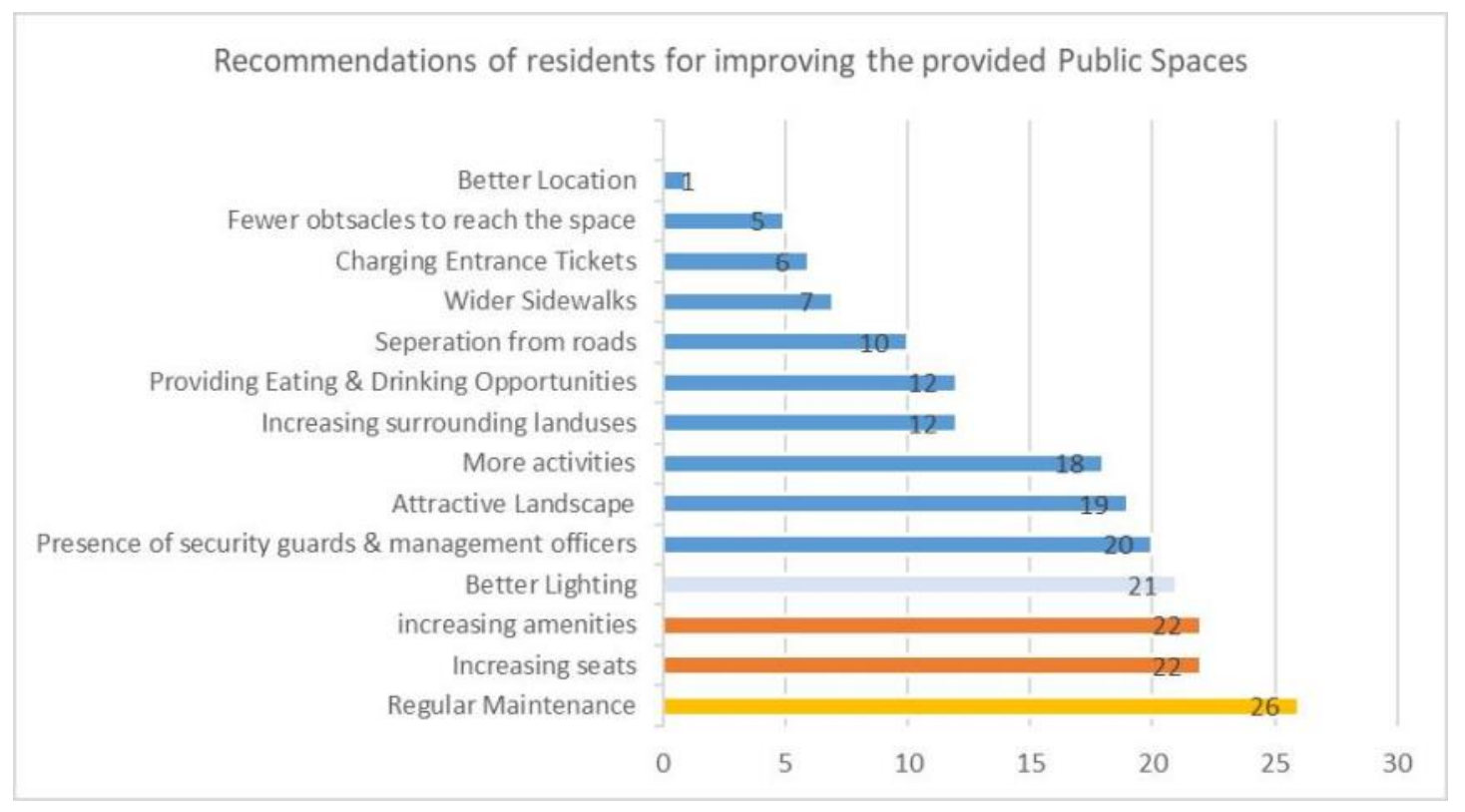

Figure 21. Recommendations of Nasr City residents for improving the public spaces in their neighborhoods which would encourage them for using these spaces. Source: The Authors

Hence if these needs are compared to the commodities that the two models of public spaces provide, it shall be obvious why the second model (peripheral spaces) of the extended cafe seating area on the edge of public spaces doesn't attract females as much as it does males. Females prioritise maintenance which is relatively low in this public space model.

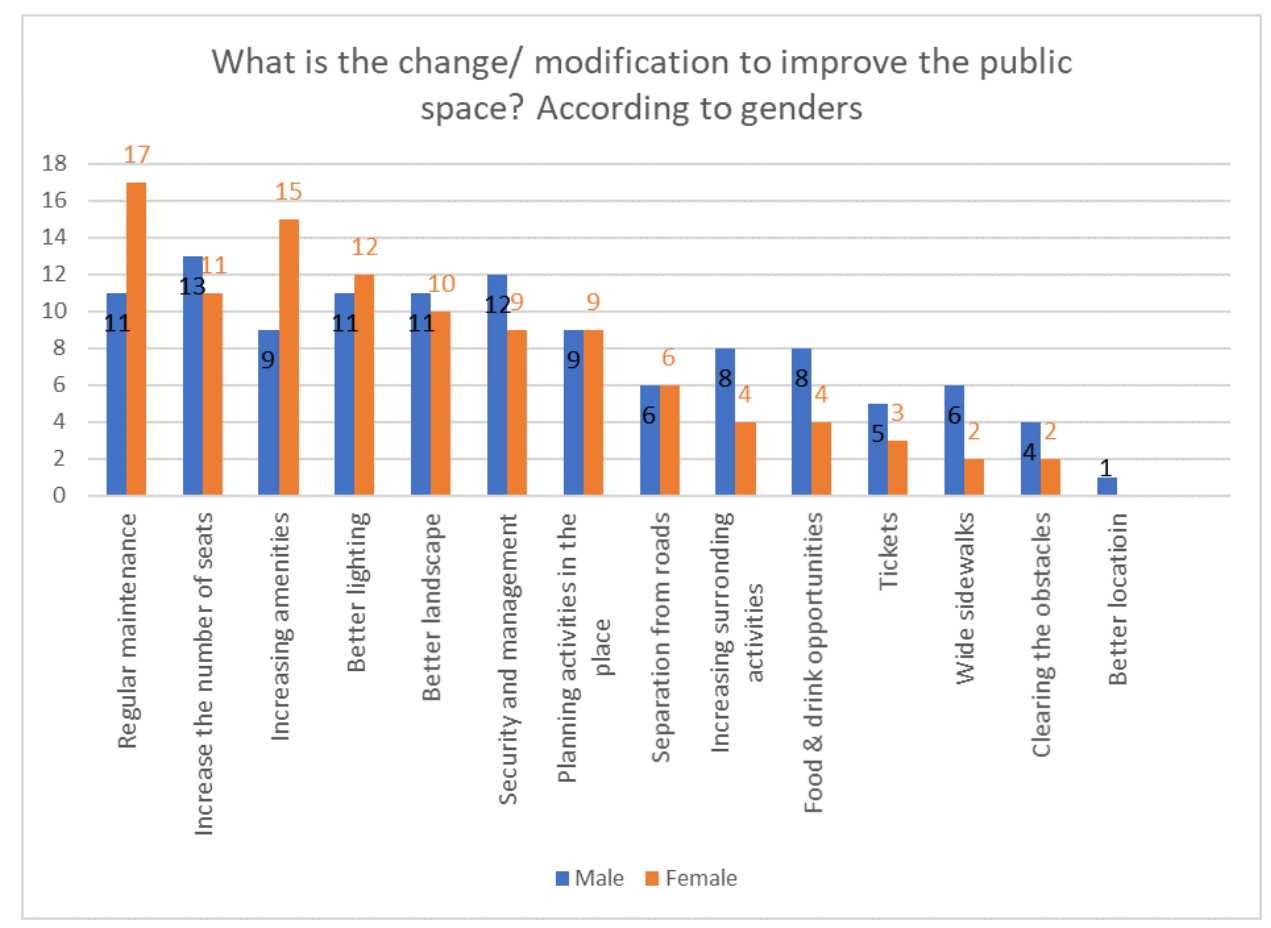

Figure 22. Nasr City residents' recommendations for improving the public spaces in their neighborhoods which would encourage them to use these spaces, according to gender. Source: The Authors

82 | The Journal of Public Space, 4(I), 2019| ISSN 2206-9658

City Space Architecture / UN-Habitat 

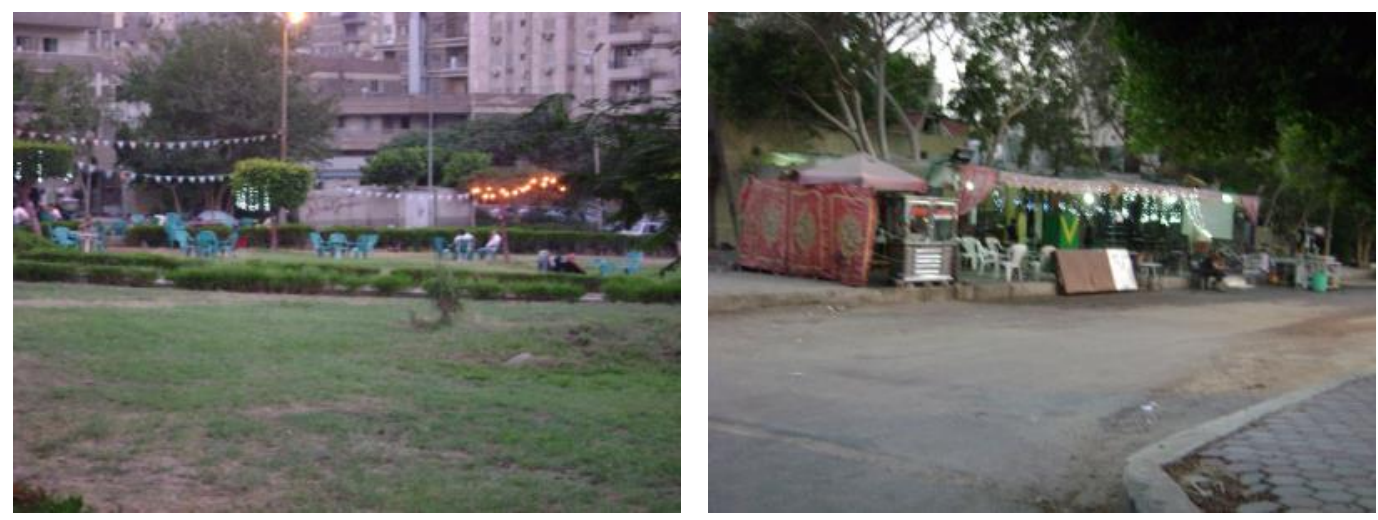

Figure 23 and Figure 24. Examples of an extended cafe seating area on nearby public space premises that usually attracts males (peripheral public spaces). Source: The Authors
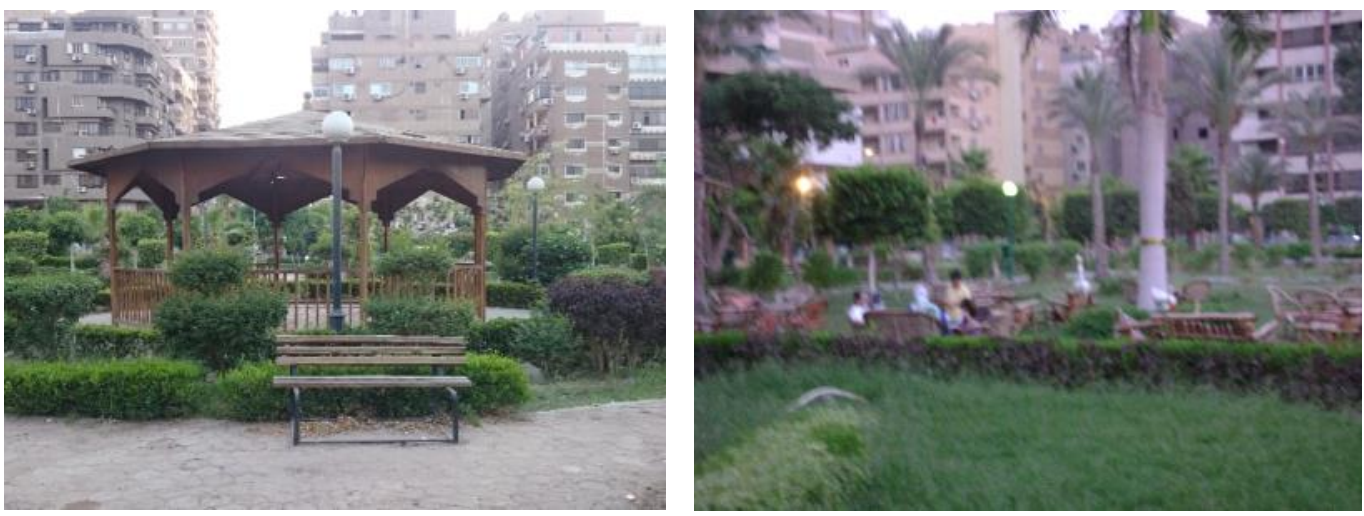

Figure 25 and Figure 26. Examples of seating areas provided within public spaces that attract almost all community segments (central public spaces). Source: The Authors.

\subsubsection{According to age sectors}

For a better and more holistic understanding of the situation, the six inclusive central spaces shall be discussed in comparison with the different needs as expressed by different age groups. The youth prioritised lighting, security presence and maintenance, while adults prioritised maintenance, an increased number of seats and better landscapes; priorities express by the elderly were similar to those of the adults, as illustrated in Figure 27. However, its worth highlighting that the youth stressed the need for the accommodation of different activities within the spaces, including eating and drinking opportunities which were viewed as priority commodities to be provided within public spaces if they were to use them.

In fact, this reveals a lot about the different needs of the different age groups, youths mainly seek leisure and fun from public spaces and so they prioritise the commodities that qualify a space to provide these rather than taking a view that spaces are mere aesthetical entities. This trend is illustrated in Figure 28, where the residents were asked what they perceived to be the function of these spaces, whilst "play" ranked high, at the same time security in and the maintenance of spaces are needed for these spaces to become their destination for fun. On the other hand, adults and the elderly tend to seek peace and quietness from these spaces, as illustrated in Figure 28, so they seek more aesthetical qualities that would help them attain a peaceful state and a suitable place in which to stay and gather. 
The first model of public spaces in Nasr City (central public spaces) provides most of the commodities that the different users seek so this explains the fact that they are relatively inclusive in comparison to the other model.

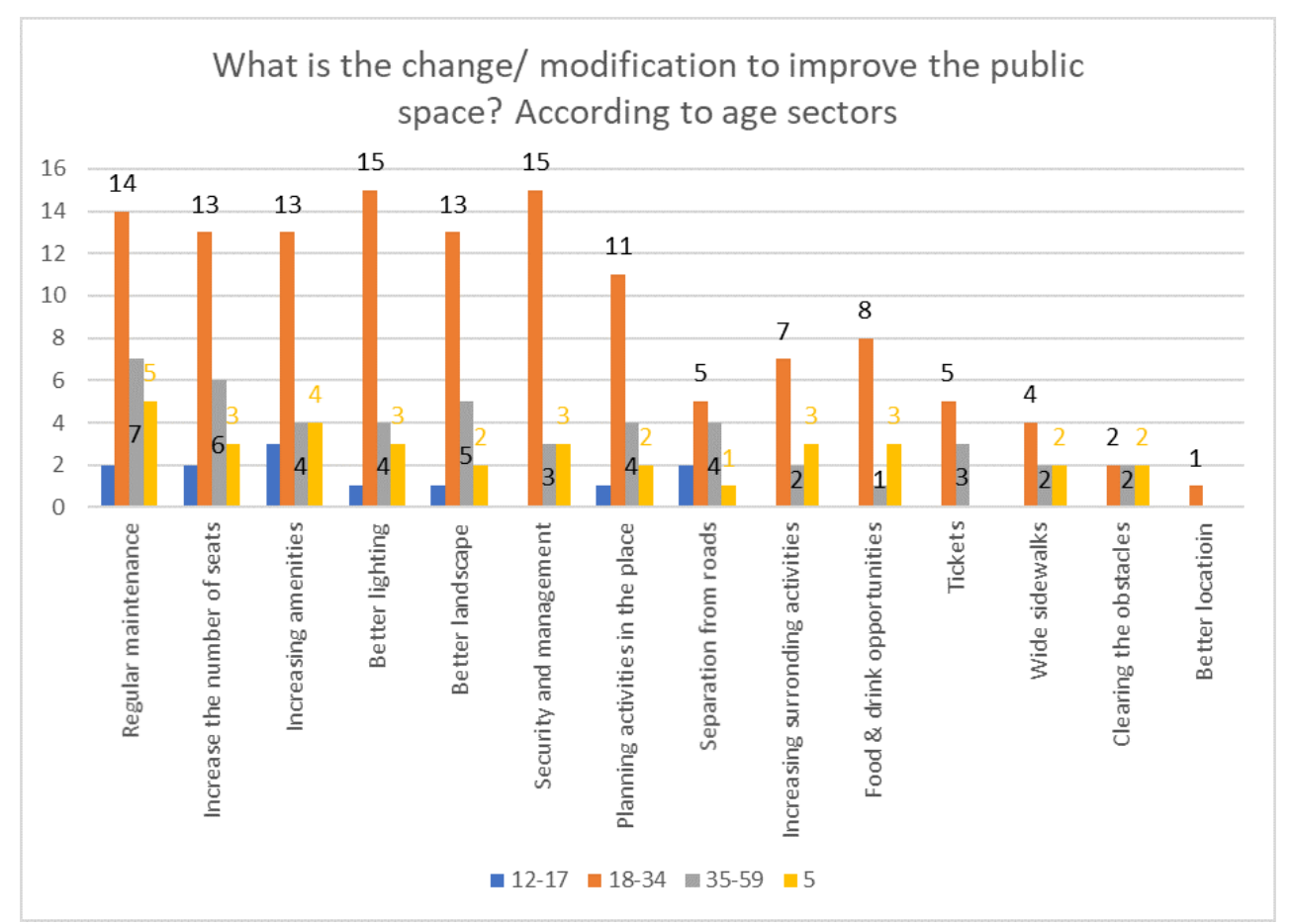

Figure 27. Recommendations of Nasr City residents for improving the public spaces in their neighborhoods which would encourage them for using these spaces, according to age sectors. Source: The Authors

What do you think these places are for?

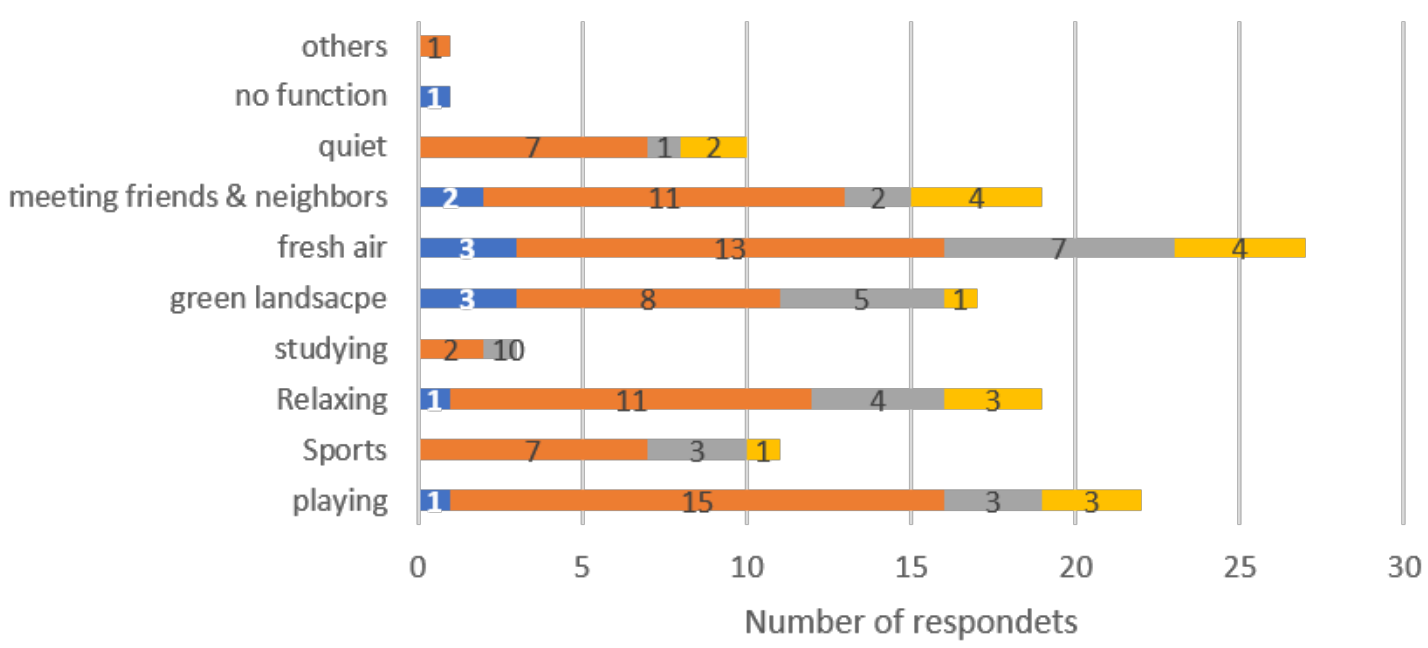

$\square$ 12-17 $\square$ 18-34 $\square 35-59 \square>60$

Figure 28 illustrates the function of the provided public spaces as perceived by Nasr City residents, categorised according to age groups. Source: The Authors 


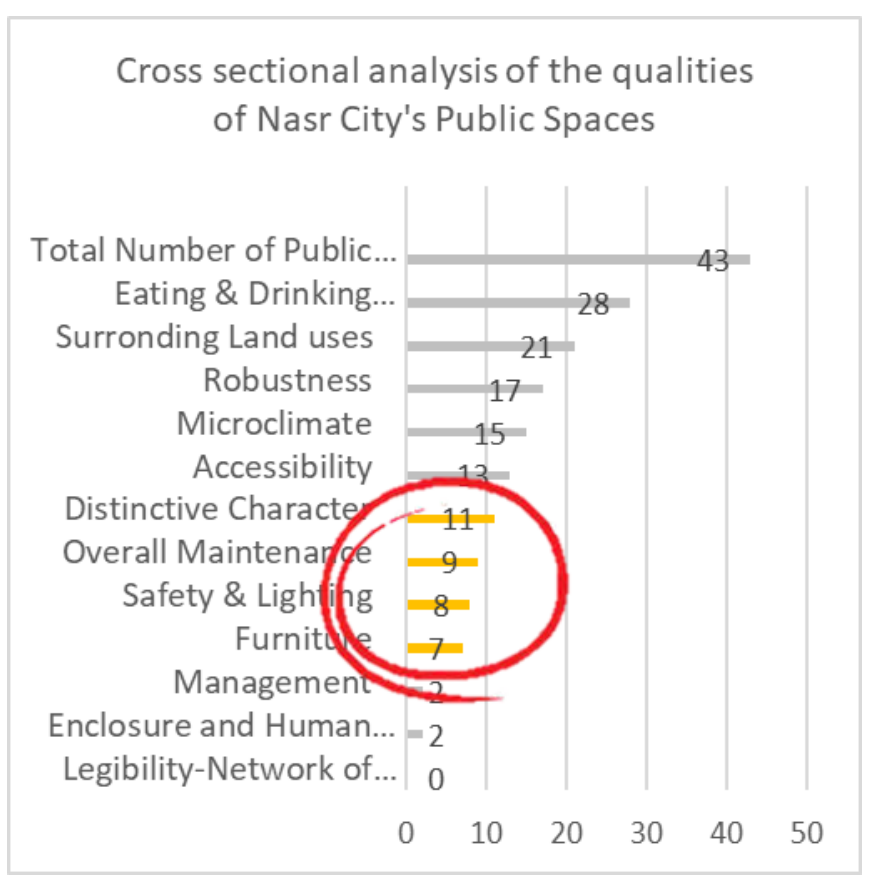

Figure 29. Relationship between the current state of public spaces in Nasr City and the needs prioritised by the residents. Source: The Authors.

\section{Discussion}

It is obvious that there is a great gap between the needs of the residents and the commodities that the current public spaces provide. If the residents' recommendations are cross-checked with the current situation in Nasr City's public spaces, as illustrated in Figure 29, it will be obvious that only less than $25 \%$ of the spaces meet the needs of the residents. This of course justifies the current state of public spaces as being devoid of people.

In addition, cars are dominating the built environment in Nasr City and there is minimal pedestrian infrastructure. The public spaces were not located in relation to the pedestrian network, which has resulted in their being perceived as destinations that are visited intentionally. Hence, the quality of these public spaces is of great importance as it directly affects decisions to visit these spaces; in Nasr City's case they are mainly sought out for leisure which degrades the comprehensive meaning of public spaces as everyday spaces for lingering, passing by, walking or waiting for someone, gathering and meeting people and friends, eating, sun bathing...etc.

The managerial approach towards public spaces defines a lot about the role that public spaces can play in the social life of neighbourhoods and by extension, the identity of cities as a whole. Reflecting on the current situation in Nasr City, there is a great need for a mindset shift if community participation and engagement is to be ensured and if spaces and neighbourhoods are to reflect their communities' identities. The results of the CCBA's failure to engage with the social aspect of public spaces highlight the importance of dealing with green areas as holistic entities and assets, and focusing in on the social aspect of the spaces. In doing so, an understanding can be reached about how to enrich and maintain social activites in addition to the physical/ecological aspects of the spaces, the main tasks of the CCBA. 
It is evident that the qualities of well-designed spaces are closely interrelated, and their effects can't be felt separately. Hence designing and managing a public space should be regarded as being a comprehensive approach which involves multiple scales with multiple dimensions.

\section{Conclusion and recommendations}

It is clear that lack of public life has contributed to the loss of identity in modern cities such as has been illustrated through analysing Nasr City in Cairo. It is argued that public spaces are the nuclei of social life in neighbourhoods as it is where the individual gets to know his community and begins thinking and acting as a part of a group; however this effect and "call to community" are not felt alike by all the residents in Nasr City in their public spaces. Just providing public spaces is not the answer to reclaiming a lost identity, it can even further complicate it. Indeed, abandoned, unused public spaces have numerous negative urban impacts on many levels; they are socially unsafe, economic drains, and are aesthetically unappealing. Thus, based on these research results, during the process of planning modern neighbourhoods and cities, great attention should be given to the locations of the public spaces within the master plan and their relationship with the surroundings, especially for efforts to regain the identity of neighbourhoods. Public spaces shouldn't be planned as an element to be fulfilled in masterplans or as a standard or a number, because the way they are situated within the neighbourhoods and the city affects their livelihoods in the future as illustrated through this research. For instance, the locations of the public spaces influence their accessibility and usability in terms of the way people perceive them; when they are located in deserted islands like the case of Nasr City, they are considered as leisure destinations. While when a market complex was situated on one side of some spaces, the activity of the complex spilled out into those spaces which motivates usage of the rest of the space.

Accordingly, this research proposes a multi-dimensional approach when dealing with public spaces in neighbourhoods based on 3 dimensions; the physical planning and design of spaces, the managerial model, and the financial model of public spaces. Through reflecting on the officials' interviews, it became obvious that the financial aspect of the spaces' management and governance is crucial for better supply. In addition, the adopted financial model may affect the inclusivity of the space and so should be considered simultaneously along with management qualities. The research suggests that the key to reclaiming the lost identity of modern neighbourhoods lies in different stakeholders committing to a holistic consideration of these dimensions, in acknowledgment that no one dimension in isolation can offer a stand-alone solution.

I. Planning and designing public spaces should be dealt with in a comprehensive multiscale approach, taking in to consideration:

- The locations of public spaces within cities' masterplans which should facilitate the flow between the surrounding land uses and public spaces in order to create a vivid environment around the clock.

- Facilitating the spill over of the different daily activities generated by the surrounding land uses as playing a key role in boosting the spontaneous livelihood of public spaces, as seen in Nasr City's public spaces that are situated next to market complexes. 
- The internal design and layout of public spaces should facilitate the movement of passers-by to encourage regular pedestrian traffic in public spaces and should offer seating and relaxation opportunities.

- The robustness of spaces in terms of their accommodating diverse activities which empowers them to effectively fulfil the role of collecting neighbours together, thereby increasing social cohesion in and exerting a positive impact on the community. The different needs expressed by each community segment are crucial here and should be prioritised.

- The needs of the different age groups and particularly vulnerable groups should be periodically and genuinely taken into consideration to ensure the inclusivity of the spaces. Safety is perceived differently by different segments and age groups, so ensuring safety through different measures is essential.

- Having access to a space with a pleasant and attractive character is not always top of the list for all groups, however working towards achieving this helps to ensure more inclusive spaces.

\section{The Managerial Model}

Prioritising people's needs is a main essential step towards attaining a vivid public realm and in turn, enhancing the identities of modern cities. This shall be realised if the social aspect of the spaces is incorporated within the mandates of the Cairo Cleaning and Beautification Agency and the municipality. Adopting standardised and contextualised methods and techniques for acurately measuring the needs and behaviour of residents through reliable and ongoing tools and methods can serve to steadily inform relevant authorites about how best to perform their urban tasks for the good of the community. On the other hand, another option would be to create a new urban body mandated with attaining liveability in neighbourhoods. A great example of this particular initiative is the Public Space Authority in Mexico City, which was established in 2009 to embrace the concept of liveability in Mexico City; the mayor believed that public spaces can be part of a wider strategy to improve the quality of life in urban areas (Scruggs, 2016). The main mandate of this authority is putting the needs of people before the needs of cars, and its motto is to "think big" employing numerous small interventions. Thus, it differs markedly from traditional departments that are saddled with maintenance responsibilities or transportation departments that manage public spaces solely in relation to city streets (ibid). This authority mainly acts as a public urban design office focused on public spaces, where all who work there have backgrounds in architecture and urbanism (ibid). These kinds of specialised authorities think holistically and prioritise people's needs and the social life of cities, rather than focusing on the mere physical aspect of the city.

Conversly, the centrality of the management model of public spaces in Nasr City hinders local solutions and practices. The municipality is the main authority body in charge of managing public spaces in Nasr City districts, however the main legislations and laws abiding this management are passed by the governor of each governorate. Thus any amendment to an existing regulation or the introduction of a new regulation is required to be passed by the governor, and shall be bidding for all the governorate's neighborhoods and districts, which in return hinders fast-track solutions, locally contextualised amendments and new legislations. In fact this centralised management model jeopardises the making of new decisions and increases the burden of these decisions on the governors, which in turn hinders them from making any new 
legislations. This centralised model also adds to the complexity of communities' engagement and empowerment and makes it more difficult to attain. The link between the residents and their officials is difficult to maintain through the busy daily life of the residents, hence creating a common platform between the residents and the officials and managerial bodies of public spaces should be prioritised if community engagement to be realised. This can only be achieved through decentralised local bodies that are capable of managing public spaces and making appropriate decisions according to different contexts, factors and circumstances.

\section{Financial model:}

Expanding the fiscal revenues of the spaces is essential in order to ensure sustainable supply and maintenance. This can be achieved in a number of ways

- Public-private partnerships: this model has already been adopted in some cases in Nasr City in spaces that now have entrance tickets, where for example the café and playground on their premises are rented through the private sector via a public auction. This practice is still not that common but there is a current trend orientated towards replicating this model. This model of incorporating commercial activities within the premises of public spaces is being adopted in the United Kingdom in an effort to counteract cuts in budgets for the maintenance of public parks and spaces (Moore, 2017). According to surveys, most people are happy about the introduction of private activities in public spaces however in such cases the ecology of these spaces, their fundamental inclusiveness and accessibility should be taken into due consideration (ibid). Often, for-profit motives don't take the long-term wellbeing of natural assets into consideration, in addition, this model ultimately excludes community members who don't have the financial capacity to pay for the tickets which grant them access to the activities occuring within the space (ibid).

On the other hand, it is worth thinking about the spaces with the cafeterias on their peripheries that already uses parts of these spaces to expand their serving areas. Legalising renting these areas, rather than continuously standing in opposition with no gain, would of course increase the municipality and the CCBA's revenues which could further serve to help them maintain these unmaintained and underused/empty spaces. In fact, these kinds of spaces with markets on their peripheries represent a great asset, the active land use facilitates a spontaneous spill-over of the activities along the peripherary into the main space. On the contrary, other central public spaces in Nasr City are surrounded by streets on all four sides, preventing this spontaneous spill-over of activity taking place in a smooth and natural fashion.

- Grass root funding: Residents' councils or CBOs can be of a great importance when it comes to increasing the funding of spaces. Engaging residents can be another viable option that requires a thorough analysis. The CCBA already has a Self-Efforts Department that is mainly concerned with the spaces that are funded by the residents but commissioned and maintained by the CCBA. There is a successful example of this model in Nasr City where the residents of the surrounding block gathered together to raise funds for a space reclamation which is a sign of the power of community in funding and reclamation initiatives for public spaces and projects. 
Adopting this multidimensional framework that includes considerations around planning and physical design, organisational and managerial dimensions, and financial dimensions would ensure the prioritisation of people's needs as a means to enhancing social life and a sense of belonging in each public space, which in turn would definitely add to the identity of neighborhoods and cities as a whole, boosting residents' pride in the process.

\section{Note}

A former version of the paper was published in the proceedings of 'The first International Conference on the Transformation of the Urban Character of Arab Cities since the late last century' International Conference held at the German Jordanian University Amman, held in Jordan on 22-24 April, 2015 , entitled 'Understanding people's needs for vivid public realm as a key towards enhancing modern Arab cities' identity' by Keleg, M, Salheen, M, and Abdellatif, M., Birmingham City University (BCU), UK. ISBN 978-I-904839-83-5.

\section{References}

Abouelmagd, D. (20II). Public Housing and Public Housing Policies in Greater Cairo. Toulouse, France, 23rd ENHR (European Network for Housing Research) conference.

Alexander, C. et al. (1977). A Pattern Language. Towns. Buildings. Construction. New York: Oxford University Press.

Batty, M. \& Longley, P. (1994). Fractal Cities: A Geometry of Form and Function. San Diego, CA and London: Academic Press.

Ben-Joseph, E. (1997). Traffic calming and the neotraditional street, p. 47-52. Available at: http://citeseerx.ist.psu.edu/viewdoc/download?doi=10.1.1.553.3237\&rep=rep /\&type=pdf

CABE (2000). By design. Urban design in the planning system: towards better practice., London: Department for communities and local government.

CABE (2006). It's our space. A guide for community groups working to improve public space., London: CABE.

CABE \& DETR (2000). by design Urban design in the planning system: towards better practice, London: Department of the Environment, Transport \& The Regions.

CABE \& DETR (200I). The value of urban design, London: CABE.

Cairo Cleaning \& Beautification Agency (2016). The Agency Mission. [Online] Available at: http://www.ccba.gov.eg/page2.php?id=162 [Accessed I June 2017].

Carmona, M., Heath, T., Oc, T. \& Tiesdell, S. (2003). Public Places, Urban Spaces. The Dimensions of Urban Design. Oxford: Architectural Press.

CCBA Projects Manager (2017). Projects Manager at the main headquarter of Cairo Cleaning and Beatification Authority [Interview] (7 June 2017).

CCBA local unit Manager (2017). Head of the local unit of Cairo Cleaning and Beatification Authority in Nasr city [Interview] (9 June 2017).

INU - Italian Institute of Urban Planners (20I3). Charter of Public Space, Rome.

Choudhury, A. (2008). Identifying The Criteria That Sustain Livable Streets, Arizona, Tucson: University of Arizona, Tucson.

Deasy, C., FAIA \& Lawsell, T. E. (1985). Designing Places for People. Ist ed. New York: WatsonGuptill.

Dougherty, D. L. (2006). Embodying The City: Identity And Use In Urban Public Space, Alexandria, Virginia: Virginia Polytechnic Institute and State University. 
Eid, Y. Y., El Khorazaty, M. ,. T., Rashed, R. ,. O. \& Sadek, W. M. (2010). Nasr City: Land Use Transformations. Al Azhar University, july, 5(16), pp. 777-789.

Efroymson, D., Ha, T. T. K. T. \& Ha, P. T. (2009). Public Spaces: How They Humanize Cities, Dhaka: HealthBridge, WBB Trust.

Frochaux, M. \& Martin, A. (2010). Nasr City. Draft ed.:ETH Studio Basel Contemporary City Institute.

Gehl Architects (2007-2009). PlaNYC Report, New York: NYCDOT. New York City, Department of Transportation.

Gehl, J. (200I). Life Between Buildings. Using Public Space. 4th ed. Copenhagen K, Denmark: The Danish Architectural Press.

Gehl Architects (20/3). Cities for people. [Online] Available at: http://gehlcitiesforpeople.dk/author/gehlblog/page/3/_Accessed 17 January 2014].

Georgopulos, D. (2005). Introduction. In: Livability I0I. What Makes a Community Livable?. New York: The American Institute of Architects, pp. 4-5.

Goheen, P. (1998). Public space and the geography of the modern city. Progress in Human Geography, 22(4), pp. 479-496.

Gomes, P. S. (2012). Factors of good public space use [Online] Available at: http://hdl.handle.net// 0773/9247 [Accessed 2 January 2013].

Herzele, A. V. \& Wiedemann, T. (2003). A monitoring tool for the provision of accessible and attractive urban green spaces. Landscape and Urban Planning, Volume 63, p. 109-126.

Jacobs, J. (196I). The dealth and life of great american cities. New York: Random House.

Júlia, P. A., Antoni, R., Pedro, B. \& Fernando, N. d. S. (2010). Planning public spaces networks towards urban cohesion. 46th ISOCARP Congress.

Krier, R. (1979). Urban Space (Stadtraum). Rizzoli international.

Lennard, S. H. C., 2004. Livable Cities. [Online] Available at: http://www.livablecities.org/articles/genius-european-square [Accessed I2 December 2013]. Living Streets (20I2). Why places matter, UK: Living Streets.

Madanipour, A. (2003). Public and Private Spaces of the City. London and New York: Routledge. 
Madinet Nasr for Housing Development (2012). www.mnhd.com/. [Online] Available at: http://www.mnhd.com/wp-content/uploads/2012/05/Company-Credentials.pdf [Accessed 2 January 20I5].

Memluk, M. Z. (20/3). Designing Urban Squares. In: Advances in Landscape Architecture. InTech., Pp. 5I3-530.

Monroy, J. (2010). Fostering culturally rich communities. In: Shanghai Manual. A Guide for Sustainable Urban Development in the 2 I st Century. Shanghai, pp. 256-284.

Moore, R. (2017). The end of parklife as we know it? The battle for Britain's green spaces. [Online] Available at: https://www.theguardian.com/uk-news/2017/jul/09/the-end-of-park-life-as-weknow-it-the-battle-for-britains-green-spaces-rowanmoore?mc cid $=5 \mathrm{~d} 0 \mathrm{e} 5 \mathrm{cea} 43 \& \mathrm{mc}$ eid $=\mathrm{c} 5 \mathrm{ef} 8 \mathrm{ab} / \mathrm{fO}$ [Accessed I2 July 2017].

Moore, R. C. \& Cosco, N. G. (2007). What makes a park inclusive and universally designed? A multi-method approach. In: P. T. Catharine Ward Thompson, ed. Open Space: People Space. London: Taylor \& Francois, pp. 85-II0.

moveDC Vision (2014). The District of Columbia's Multimodal Long-Range Transportation Plan, Washington, DC: District Department of Transportation.

Municipal Spatial Planning Support Programme - MuSPP (2012). Turning Spaces into Places, Kosovo: Swedish Government, Sida.

North West Regional Development Agency (2008). Places matter! Creating inspirational spaces, Northwest of England: Renew NorthWest.

Oktay, D. (2012). Livable public urban spaces as essentials of human sustainable urbanism. Ankara, AESOP.

Project for Public Spaces (20I4). pps.org [Online] Available at: http://www.pps.org/reference/lObenefits/ [Accessed 2I September 2014].

Project for Public Spaces (2015). http://www.pps.org/. [Online] Available at: http://www.pps.org/blog/placemaking-and-place-led-development-a-newparadigm-for-cities-of-the-future/ [Accessed 25 February 2015].

Ratio Architects, I. (2003). City of Evansville Downtown Development \& Design Guidelines- Public Spaces, Evansville: City of Evansville.

Regeneration Group Strategic Planning \& Environment, Cardiff County Council (20I4). Public Realm Manual Cardiff City Center, Cardiff City: Cardiff County Council. 
Renew, G. L. (2008). Creating inspirational spaces, Places matter!, Northwest of England: RENEW NorthWest, Gillespies LLP.

Samadi, Z. H. \& Hasbullah, M. N. (2008). The enhancement of spaces in between buildings as urban recreation development. Kota Bharu, Kelantan, Malaysia, ECER Regional Conference.

Scruggs, G. (2016). What Mexico City learned by devoting an office to designing public spaces. [Online] Available at: http://citiscope.org/story/2016/what-mexico-city-learned-devotingoffice-designing-public-spaces/ [Accessed I4 May 2016].

Serdoura, F. M. \& Ribeiro, J. M. (2006). Public space, place of urban life. Engenharia Civil, Volume 27, pp. $5-16$.

Shaftoe, H. (2008). Convivial Urban Spaces, Creating effective public spaces. London: Earthscan in the UK and USA.

Shaw, P. \& Hudson, J. (2009). The Qualities of Informal Space: (Re)appropriation within the informal, interstitial spaces of the city. Brighton, SAGE publications.

Stevens, Q. (2007). The Ludic City. Exploring the potential of public spaces. Abingdon: Routledge.

The Athens Charter (1933). The Athens Charter, Athens: The Congrès internationaux d'architecture moderne 4 (CIAM 4).

Tibbalds, F. (2004). Making People-Friendly Towns. 3rd ed. London: Spon Press.

UrbSpace (2008). Urban spaces - enhancing the attractiveness and quality of the urban environment, Slovakia: s.n.

United Nations (1990). Population Growth and Policies in Mega Cities, New York: United Nations. Walljasper, J. 2(007). The Great Neighborhood Book, Canada: New Society Publishers.

Watson, G. B. \& Bentley, I. (2007). Identity by Design. Oxford: Elsevier Ltd.

Wellington City Coucil, 2008. Wellington City Council. [Online]

Available at: http://wellington.govt.nz/ /media/your-council/meetings/Committees/Strategyand-Policy-Committee/2008/06/I8/files/10_app_2_public_space_design_guide.pdf [Accessed I5 January 20I3].

Whyte, W. (1980). The Social life of small public spaces. New York: Project for Public Spaces.

Whyte, W. H. (2009). City. Rediscovering the Center. Philadelphia, Pennsylvania: University of Pennsylvania Press.

Worpole, K. \& Knox, K. (2007). The social value of public spaces, UK and Wales: Joseph Rowntree Foundation.

Victoria, A. (2008). The Role of Arts and Culture in Liveability and Competitiveness, Precis. 